\title{
QUEEN'S
UNIVERSITY
BELFAST
}

\section{The role of the media in a bubble}

Campbell, G., Turner, J. D., \& Walker, C. B. (2012). The role of the media in a bubble. Explorations in Economic History, 49(4), 461-481. https://doi.org/10.1016/j.eeh.2012.07.002

\author{
Published in: \\ Explorations in Economic History
}

Document Version:

Peer reviewed version

Queen's University Belfast - Research Portal:

Link to publication record in Queen's University Belfast Research Portal

\section{Publisher rights}

(C) 2012 Elsevier Inc

This is the author's version of a work that was accepted for publication in Explorations in Economic History. Changes resulting from the publishing process, such as peer review, editing, corrections, structural formatting, and other quality control mechanisms may not be reflected in this document. Changes may have been made to this work since it was submitted for publication. A definitive version was subsequently published in Explorations in Economic History, Vol. 49, 10/2012.

\section{General rights}

Copyright for the publications made accessible via the Queen's University Belfast Research Portal is retained by the author(s) and / or other copyright owners and it is a condition of accessing these publications that users recognise and abide by the legal requirements associated with these rights.

\section{Take down policy}

The Research Portal is Queen's institutional repository that provides access to Queen's research output. Every effort has been made to ensure that content in the Research Portal does not infringe any person's rights, or applicable UK laws. If you discover content in the Research Portal that you believe breaches copyright or violates any law, please contact openaccess@qub.ac.uk. 


\section{Accepted Manuscript}

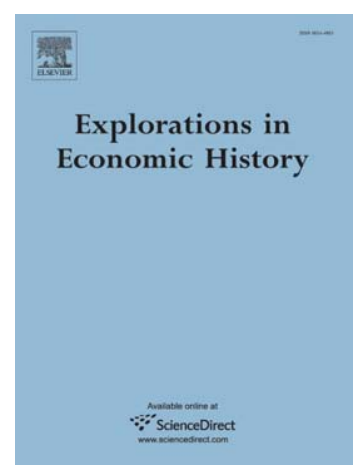

The Role of the Media in a Bubble

Gareth Campbell, John D. Turner, Clive B. Walker

PII: $\quad$ S0014-4983(12)00041-1

DOI: $\quad$ doi: $10.1016 /$ j.eeh.2012.07.002

Reference: $\quad$ YEXEH 1084

To appear in: $\quad$ Explorations in Economic History

Received date: $\quad 29$ February 2012

Please cite this article as: Campbell, Gareth, Turner, John D., Walker, Clive B., The Role of the Media in a Bubble, Explorations in Economic History (2012), doi: 10.1016/j.eeh.2012.07.002

This is a PDF file of an unedited manuscript that has been accepted for publication. As a service to our customers we are providing this early version of the manuscript. The manuscript will undergo copyediting, typesetting, and review of the resulting proof before it is published in its final form. Please note that during the production process errors may be discovered which could affect the content, and all legal disclaimers that apply to the journal pertain. 


\title{
The Role of the Media in a Bubble
}

\author{
Gareth Campbell, John D. Turner and Clive B. Walker \\ Queen's University Management School \\ Queen's University Belfast \\ gareth.campbell@qub.ac.uk \\ j.turner@qub.ac.uk \\ cwalker11@qub.ac.uk
}

\begin{abstract}
We examine the role of the news media during the British Railway Mania, arguably one of the largest financial bubbles in history. Our analysis suggests that the press responded to changes in the stock market, and its reporting of recent events may have influenced asset prices. However, we find no evidence that the sentiment of the media, or the attention which it gave to particular stocks, had any influence on exacerbating or ending the Mania. The main contribution of the media was to provide factual information which investors could use to inform their decisions.
\end{abstract}

Thanks to the ESRC (RES-000-22-1391) for financial support. Campbell and Walker acknowledge the financial support of DEL. Turner acknowledges the support of Harvard Business School, where some of this research was conducted during his tenure as the Alfred D. Chandler Fellow. Earlier versions of this paper were presented at the Economic History Society conference in Cambridge, the BETA Historical Economics Workshop in Strasbourg, the European Historical Economics conference in Dublin, and the EFRG seminar and the EFIRG workshop at Queen's University Belfast. Thanks to participants at those conferences for their suggestions. In particular, thanks to Graham Brownlow, Graeme Acheson, Gerben Bakker, Dan Bogart, Carsten Burhop, Mark Casson, David Chambers, Les Hannah, Gerhard Kling, Michael Moore, Luke Samy, James Taylor, Steven Wu and Qing Ye for their comments. 


\section{Introduction}

In this paper, we analyse the role of the news media during the Railway Mania which occurred in Britain in the mid-1840s. During this episode, hundreds of new railways were promoted and railway stocks experienced a substantial asset price reversal. Contemporaries and modern commentators have both suggested that this period was one of the greatest bubbles in economic history (Mackay, 1856; Economist, 2008).

The scale and consequences of the asset price reversals which occurred in technology stocks during the Dot-Com Bubble and in property during the Housing Bubble makes an understanding of such episodes particularly important. The role of the news media is of special concern as it may play a crucial feedback role in exacerbating price movements by publicising recent changes which draw new investors into the market, and by shaping public opinion through their coverage of new-era stories which justify high asset prices (Akerlof and Shiller, 2009, p.55). Shiller (2005, p.105) has gone so far as to suggest that the news media are 'fundamental propagators of speculative price movements through their efforts to make news interesting to their audience'. The only paper to test directly Shiller's hypothesis is Bhattacharya et al. (2009), who find that media hype does not explain the Dot-Com Bubble. However, recent studies, which do not focus on bubble episodes per se, have suggested that the media can affect investor sentiment (Tetlock, 2007; Engelberg and Parsons, 2011; Dougal et al., 2012). By examining the relationship between the media and the market in an historical and non-US context, we can determine whether these recent findings regarding the role of the media are robust across time and space. Our main finding is that although media coverage responded to events, and played a role in disseminating information, it did not amplify the extent of the asset price reversal during the Mania or contribute to its bursting.

An analysis of the effect of the news media during the Railway Mania is particularly pertinent for at least four reasons. First, newspapers and periodicals were the only source of 
information for most investors during the 1840 s as there was no analyst or institutional coverage of stocks and companies were not typically required to distribute financial accounts to stockholders (Baskin and Miranti, 1997; Cheffins, 2008). Consequently, one would expect news media coverage to be a potentially influential source of information, which could easily be hyped. Second, the 1840s marked the beginning of extensive press coverage of financial markets by the British news media (Preda, 2001; Taylor, 2012), which means we are examining the influence of media on financial markets at the origin. Third, the railway periodicals of the time had a large incentive to hype the Mania and keep it going as they received substantial amounts of revenue from advertising the prospectuses of new railways. Fourth, The Times, the leading daily newspaper at the time, along with the Economist, was accused of causing the market collapse through a series of critical editorials. Hence, we have a ready-made hypothesis regarding the media.

To determine the nature of coverage during the Mania, we use two approaches to quantifying the sentiment of media articles at this time. Firstly, we collected every editorial article in the Railway Times, as well as the front page of the Economist and its weekly railway supplement, and converted them to text files. We then apply Linguistic Inquiry and Word Count (LIWC) content analysis software to this database of media articles in order to evaluate the scale (word count) and positivity of media coverage. Secondly, we manually evaluated articles in a two-year window either side of the Mania peak, and give a subjective assessment of how positive each article was in its tone. This allows us to ensure that the content was relevant to shareholders, and makes it possible to distinguish between the reporting of past events and the forecasting of future developments.

To evaluate the impact of the media on asset prices, we collected weekly stock prices for the 591 railway stocks (representing 332 railway companies) and a sample of 22 of the largest non-railway companies which were traded on the London Stock Exchange. Then, 
using this data to form indices of railway and non-railway stocks, we estimate Newey-West regressions to see how stock returns were related to the scale and positivity of news media coverage in the railway press.

As The Times and Economist were accused of bursting the bubble through a series of highly critical editorials, we also use an event study methodology to see if the market for railway stocks reacted negatively to these editorials.

Although the tone of coverage is the most direct way by which the media could affect investor sentiment, it is also possible that the extent of coverage could exacerbate price movements as investors may be more likely to purchase a stock which receives more attention. To address this issue, we also test whether the amount of coverage received by individual stocks resulted in them having higher returns. Each text file from the Railway Times and the Economist's railway supplement was searched, and the number of times that each railway company was mentioned was recorded. Portfolios of stocks were then formed according to whether stocks received extensive, low or no media coverage, and the returns on these portfolios were analysed, controlling for standard risk factors.

We find evidence that the media responded to stock returns, for example by commenting on a stock market crash, and there is a suggestion that stock returns responded to the reporting of events which had already occurred. However, we find no evidence that the forecasts made by the media had any impact on stock prices, and consequently, contrary to Shiller's (2005) claim, the media cannot be said to have played an important role in exacerbating the Mania for investing. In addition, our findings from the event studies imply that The Times and Economist were not responsible for bringing the asset price reversal to an end, contrary to the claims of contemporaries. We also find that the coverage of individual stocks did not affect their returns, once other factors are controlled for. Consequently, although we find that media coverage varied over the course of the Mania, this was in 
response to events, and the media cannot be regarded as necessarily contributing to the changes. The main role of the media was to report factual information.

Our paper is closely related to a broader literature which examines the role of the media in financial markets. At the microscopic level, there is some evidence that news media coverage can affect the prices of individual stocks even though no new information is released (Huberman and Regev, 2001; Fang and Peress, 2009). At the aggregate level, Cutler et al. (1989) suggests that large stock-market movements are not necessarily explained by media coverage of important events. More recently, however, Tetlock $(2007,2010)$ finds evidence that news media coverage is connected to subsequent stock market movements, suggesting that the media affects investor sentiment. Engelberg and Parsons (2011) disentangle the causal impact of news media, finding that media coverage alters investment behaviour, whilst Dougal et al. (2012) find that the news media affects the stock market by amplifying or attenuating current investor sentiment.

Given the potential conflicts of interest and bias of the railway press, this paper also contributes to the literature on biases within financial news media. For example, Dyck and Zingales $(2003 \mathrm{a}, \mathrm{b})$ argue that financial reporters have incentives to enter into quid pro quo relationships with their sources so as to obtain private information, but in return they provide a positive spin on companies' news. During booms, the value of this relationship is higher, implying that the pro-company bias in the press will be greater, thus fuelling asset price bubbles. Reuter and Zitzewitz (2006) find that the personal finance publications, but not the national press, exhibit a bias towards mutual funds which advertise in previous issues. Bignon and Miscio (2010) find existence of a media bias in early twentieth-century France, where companies had to make payments for coverage in newspapers' editorial sections. The theoretical literature on media bias argues that it can be reduced by competition in the media market and independent sources of ex post news verification (Gentzkow and Shapiro, 2006) 
as well as reader heterogeneity (Mullainathan and Shleifer 2005). Notably, in the case of the Railway Mania, there was intense competition between multiple railway periodicals and reader heterogeneity in terms of class, wealth and socio-occupational status (Parliamentary Papers, 1845, 1846).

The rest of the paper is structured as follows. Section two reviews the background to the Railway Mania and the concomitant rise of the financial press. Section three outlines our empirical strategy and data. Section four reports the findings on the scale and positivity of the media during the Mania. Section five examines the relationship between news media coverage and market returns. Section six examines whether the critical editorials in The Times and Economist played a role in ending the Mania. Section seven examines the media coverage of individual companies to ascertain whether the scale of media coverage affected individual stock returns. Section eight discusses the role of the media in providing information during the Mania. The final section is a brief discussion and overview of our findings.

\section{The Railway Mania and the financial press}

The Railway Mania is viewed as one of the greatest bubbles in history because over 1,000 railway companies were promoted during 1844-45 and, contemporaneously, a comprehensive index of railway stocks doubled between mid-1843 and the summer of 1845, as shown in Figure 1. However, the market for railway stocks declined precipitously in the fall of 1845, and ended the decade well below the level of 1843. In the process, many newly-promoted railway schemes were aborted or merged with other companies. Nevertheless, the railway system expanded rapidly as a result of the Mania, with the network which endured into the twentieth century being largely in place by 1852 (Mitchell, 1964, pp.315-6). 
Although this episode has sometimes been explained as mania, delusion and irrational behaviour on the part of investors (Francis, 1851; Hyndman, 1892, p.55; Lewin, 1936; Gayer et al., 1953, p.380; Simmons, 1978; Kindleberger, 1984, p.201), there were considerable changes in fundamental factors, such as dividends, at this time (Campbell, 2012). However, as we shall see below, there were also important changes in the scale and content of media coverage of the railways throughout this period.

There were several newspapers dedicated to commenting on the railway industry. This railway press arose largely to meet the information needs of the popular investor who had become increasingly important in the years preceding the Mania (Preda, 2001). These periodicals carried share price tables, editorial commentary on the railway sector and railway stocks, letters from readers, company financial reports, reports of company AGMs, and advertisements from railway promoters seeking investors. Of the three largest railway periodicals, the Railway Times had by far the widest circulation, as shown in Table 1, and the median circulation in 1845 of the other 16 periodicals was only 10,750 (Parliamentary Papers, 1852).

\section{$<<$ INSERT TABLE $1>>$}

Unsurprisingly, for a periodical which was read by railway investors and which received an estimated $£ 14,000$ ( $£ 1.12 \mathrm{~m}$ in today’s money) a week from advertisements paid for by railway companies (Kostal, 1994, p.37), the Railway Times was sympathetic to the railway industry. During the boom, they agreed that many of the companies would be good investments, and in the midst of the market crash in October 1845 they argued that it was the work of brokers and jobbers 'to get possession of valuable stock at reduced prices.'

There was also considerable commentary on the railways from the mainstream press.

\footnotetext{
${ }^{1}$ Railway Times, October 18, 1845, p.1961
} 
The Times, which, as can be seen from Table 1, was by some distance the leading daily newspaper in 1845 in terms of circulation and influence (Simmons, 1991, p.240) ${ }^{2}$, discussed the railways extensively in a series of editorials. ${ }^{3}$ These articles were extremely critical of what The Times believed to be excessive speculation in railway shares. For example, on the weekend prior to the beginning of the market crash, October 181845 , they said that 'the mania for railway speculation has reached that height at which all follies, however absurd in themselves, cease to be ludicrous, and become, by reason of their universality, fit subjects for the politician to consider as well as the moralist. ${ }^{4}$ Several weeks later they published what has been termed an exposé of the madness of railway speculation (Simmons, 1978, p.40). Contemporaries accused The Times of bearing the market for gain and ultimately causing the market for railway stocks to collapse (Tuck, 1846). The leading article in the Railway Times each week between October 18 and December 13, 1845 focused on the role of The Times in causing the collapse of the market for railway stocks.

The Economist, which had begun publication in 1843, also criticised the speculation in railway shares. It had quickly become known as an influential commentator on political economy and provided detailed analysis of the potential consequences of the Mania. They published a particularly strongly worded article opposing railway speculation on April 5 1845, five months prior to the market crash. They argued that new railway construction would 'form a severe drain on the available capital of the country,' and that it would be 'discovered that a large portion who hold shares have done so only on speculation; that they are unable to pay their calls; and all the weaker undertakings will be suspended for want of

\footnotetext{
${ }^{2}$ These figures do not capture the full readership of The Times as it was commonly passed on to others and read aloud in public houses (Brown, 1985, pp.27-9, 50).

${ }^{3}$ By the 1840 s, The Times was printing lists of stock prices (including railways) and giving a brief comment on activity in the money and government debt markets. It was only at the beginning of 1846 that there was a section of the paper devoted solely to the market for railway stocks. This section usually contained a very brief (one or two sentences) factual report on the level of activity in the market for railway stocks.

${ }^{4}$ The Times, October 18, 1845, p.5
} 
capital'. 5 In addition to editorials in the main paper, the Economist also included a separate section dedicated to the railways from January 1845 , which was then expanded to become the Railway Monitor supplement in October 1845, just a few weeks prior to the market crash. This supplement in its first issue contained an extensive discussion of why the extent of new railway promotion was unsustainable, and would result in much 'temporary mischief., 6

In addition to newspapers, there were several other sources which investors may have used. There were a number of pamphlets which offered general investment advice to inexperienced investors. For example, the Short and Sure Guide to Railway Speculation advised that with 'regards the purchase of shares in established lines we have simply to compare the market price of the share with the dividend which it pays ${ }^{7}$, and that for shares in a newly projected line the investor 'must know the country through which the line is to pass, and its prospects as to traffic, or he must have good reason to depend on the character of the Provisional Committee ${ }^{8}$. The Railway Investment Guide gave practical advice on how to subscribe to schemes and advised that share prices may be raised by a decision of the Parliamentary Committee in favour of the particular line, or by an amalgamation with a competitor $^{9}$. However, these guides did not provide share tips on individual companies, nor did their sentiment change over time. In addition, evidence from subscriber lists and shareholder records suggests that only a small proportion of investors during the Mania could have been regarded as inexperienced (Campbell and Turner, 2012), so the impact of these publications may have been limited.

Other sources for investors were compilations of factual information, such as Tuck's Railway Shareholder Manual which provided details on the routes taken by particular railways, and relevant parliamentary bills. Although these publications may have been useful

\footnotetext{
${ }^{5}$ Economist, April 5, 1845, p.310,

${ }^{6}$ Economist, October 4, 1845, p.949

${ }^{7}$ Short and Sure Guide to Railway Speculation, 1845, p.5

${ }^{8}$ Short and Sure Guide to Railway Speculation, 1845, p.9

${ }^{9}$ Railway Investment Guide, 1845, p.13
} 
to some individuals, they did not provide commentary on the prospects of firms or the stock market, and the surviving records suggest that by far the main source of information was the railway press which arose to satisfy the needs of railway shareholders (Simmons, 1991, p.43). Although we cannot know what investors at the time were thinking, we can infer from advice given in the investment pamphlets mentioned above, in the Railway Times, and in advertisements of new schemes, that dividends and forecasted dividends played a central role in the thinking of investors.

\section{Data}

To pursue our analysis, we have collected three types of data. Firstly, we have considered the periodicals which were dedicated to the railway industry, and reported on it every week. We have digitised every page of the Railway Times from 1843 to 1850 inclusive, and every page of the Economist's railway section and its Railway Monitor supplement from their initial publication in January 1845 until the end of $1850 .{ }^{10}$ We have also collected the front page of the Economist from it was first published in September 1843 until 1850, to estimate the effect that media coverage of economic news may have had on stock returns. Then, using OCR (Optical Character Recognition) technology, we converted each column and page into a series of text files which could be analysed. Each column was also manually categorised into editorials, letters to the editor, company and parliamentary reports, and adverts.

Secondly, we searched online digital archives of The Times and the Economist for all editorials / lead articles which related to the railway market and industry from 1843 to $1850 .^{11}$ We then manually checked all of these results and assessed whether they focused on the

\footnotetext{
${ }^{10}$ The Economist published a railway section in its main paper between January 1845 and October 1845 , and a supplement entitled the Railway Monitor from October 1845 onwards, but these are regarded as the same publication for this analysis. There were six weeks when full issues of the Railway Times, and three weeks when the Economist's railway supplement, could not be located. It was assumed that during these weeks all variables had the same values as in the previous week.

${ }^{11}$ By the 1840s, The Times was printing lists of stock prices (including railways) and giving a brief factual comment on activity in the money, equity and government debt markets.
} 
railways, or just mentioned them briefly. Using this method, we found 16 editorials in the Economist and 41 in The Times which concentrated on the railways. ${ }^{12}$

Thirdly, to assess the effect of the press on the market, we hand collected railway stock prices and capitalisation data for the 417 weeks in the sample period from share price tables in the Railway Times. In total, we found information on prices, par values and number of shares in issue for 591 ordinary stocks, belonging to 332 railway companies. We have also collected similar data from the Course of the Exchange for the 22 largest non-railway company stocks traded on the London stock market. Weekly value-weighted indices of returns were constructed for railways and non-railways using this data. The weekly returns for each stock in the indices were weighted by the previous week's market capitalisation.

On a weekly basis, the total number of observations for when stocks were listed on the stock market (number of stocks $*$ number of weeks listed) was 74,877 . The number of observations for which there was a weekly price, indicating that a trade had taken place at least once during that week, was 33,303 (44.4\% of the total). The cross-sectional analysis in Section 7 was completed on a monthly basis, and only included the primary asset type for each company. On a monthly basis, there were 10,524 observations for listed companies, and 5,667 observed prices (53.8\% of the total). If a price was not observed during a particular week or month it was assumed that the price did not change during that period, and the return was zero.

\section{Scale and positivity of railway press coverage}

To assess the coverage of the railway-specific periodicals during this episode presents the challenge of quantifying newspaper articles. There are two possible approaches which can be used for this. The first possibility is to use computer software which maintains an objective

\footnotetext{
${ }^{12}$ The editorials from The Times were obtained from the The Times Digital Archive. Several editorials occurred during the same week so the number of weeks in which an editorial occurred was 39 .
} 
and consistent approach to the scoring of different articles. The second possibility is to assess the positivity of content by reading the articles and scoring them subjectively. To ensure robustness in this analysis, we have used both approaches.

The use of computer software has several advantages over subjective assessment. Firstly, the assessor's idea of what is positive and negative may change with every article read, making a systematic evaluation of the tone of articles difficult. Secondly, with no predefined method of ascertaining whether articles are positive or negative, the decision is largely a subjective one, and this introduces the potential for bias. Thirdly, given the complex nature of language, it would be difficult to construct manually a spectrum of article positivity, which is necessary for our analysis. A possible solution to these difficulties is to quantify media content in a similar manner to Tetlock (2007), by putting each article through content analysis software. By focusing on the positivity of articles, it is possible to avoid the problem that many words considered as negative in other contexts may not be negative in financial contexts (Loughran and McDonald, 2011).

Linguistic Inquiry and Word Count (LIWC) analyzes text files using a 4,500 word corpus to score language for certain linguistic and psychological features using an in-built psychosocial dictionary. The main LIWC category of interest for our study is positivity; the in-built dictionary for this category has 406 words. When an article is analyzed by LIWC, it is given a positive score, which is simply the percentage of words in the article which are designated as positive by LIWC's in-built psychosocial dictionary. We score the positivity of each article by dividing the number of positive words by the total number of words in the article minus all linguistic processes such as pronouns, articles, conjunctions etc. Each available article between 1843 and 1850, in the Railway Times' editorial section, the Economist's railway supplement, and the Economist's front page was analysed using this approach. 
However, there are also several disadvantages to using computer software to score positivity. Firstly, sentence structure is not captured, e.g., 'no need for fear' would most probably be interpreted as a negative phrase as $75 \%$ of the words used are in the negative dictionary. Secondly, software does not distinguish between media reporting of past events, and forecasts of what is likely to happen in the future. This makes it difficult to conclude whether the media has an impact on a 'bubble' because it conveys factual information, or because it makes optimistic predictions which hype the market and increase investor expectations. Thirdly, the use of computer software cannot assess how relevant the positive words used in an article are to shareholders. For example, an article may be discussing the reduction of fares charged by a railway, which would be positive for passengers, but not necessarily so for investors. Fourthly, language use may have changed between the 1840s and today.

To overcome these difficulties we have also manually read articles and subjectively assessed positivity. Given the time consuming nature of this process we have focused on the four year period around the market peak, namely October 1843 to October 1847. Each column of each article was given a score of +1 for positive content, 0 for neutral content, or 1 for negative content, and the average across columns for each publication in each week was calculated. Separate scores have been given for the reporting of past events, and the forecasting of future developments. We have also limited our assessment to those issues which were directly relevant to shareholders.

Before analyzing positivity, it is also informative to briefly consider the word count of each publication. An analysis of all sections of the Railway Times, illustrates that it relied heavily upon advertising revenue from companies publishing prospectuses and raising capital: such advertising was on average $26.3 \%$ of the periodical's weekly word count from 1843 to 1850 . Table 2 shows that advertising was a particularly large proportion of the 
Railway Times in 1845, the year when railway stocks appreciated the most. Consequently, one could hypothesise that its editorial slant may have been biased, and they therefore had incentives to hype the market for railway shares. On the other hand, the Economist did not face such incentives, and was actually sceptical about the state of the railway share market in the weeks leading up to its collapse.

\section{$<<$ INSERT TABLE $2>>$}

Table 3 contains descriptive statistics of word count as well as the LIWC measure of the positivity of articles in the Railway Times' editorial section, the railway supplement of the Economist and the front page of the Economist. In terms of word count, the size of the average editorial section in the Railway Times decreased somewhat during 1844, possibly because the extent of space taken up by advertising increased dramatically during this period, as shown in Table 2. The word count of the Economist's railway section expanded dramatically in late 1845 when it commenced the publication of its Railway Monitor supplement. After peaking in 1846, the Economist's coverage of railways dropped substantially over the remainder of the decade.

\section{$<<$ INSERT TABLE 3>>}

In terms of sentiment, using the LIWC software suggests that the positivity of the Railway Times' editorial section almost tracked the railway stock index until mid-1848, whenever the two series diverge, as shown in Panel A of Figure 1. The average positivity of the Railway Times' editorial section was at its highest in 1845, when the Mania peaked, and in 1850 , when railway prices were recovering from their trough. The positivity of the Economist's railway supplement started high in 1845 , but declined until 1847, thereafter it increased until the end of the decade, as shown in Panel A of Figure 2. The positivity of the Economist's front page declined most dramatically in late 1846 and early 1847, as shown in Panel of Figure 3, when concerns began about the agricultural harvest and export of bullion, 
which eventually led to the Commercial Crisis of 1847.

$<<$ INSERT FIGURES 1,2 and $3>>$

Using the second approach, of subjective assessments, gives more insight into the differences between the tone of reporting, and the forecasts made, by each publication. Panel B of Figure 1 suggests that the positivity of both reporting and forecasting by the Railway Times increased during the boom, but the tenor remained fairly restrained. Even during the boom, the reporting often focused on neutral issues such as parliamentary procedure ${ }^{13}$, or on negative developments such as a proposed Parliamentary Bill which it referred to as the Railway Plunder Bill ${ }^{14}$, or on the damaging effect of competition between rival companies. ${ }^{15}$

Although the forecasts made by the Railway Times were consistently more positive than their reporting of recent events, they tended to focus on the merits of a proposed scheme, rather than on the potential for short-term speculation. For example, in their support of the Caledonian railway they said that 'the traffic tables bear out to the full, and more, the original expectations of the promoters. ${ }^{16}$ They argued that with regards the Manchester, Midland and Great Grimsby Junction railway, 'for directness and shortness it is unequalled by any of the competing schemes. ${ }^{17}$ Their assessments of proposed schemes could also be strongly critical, with one of the largest projects, the London and York railway, being referred to as a 'monster bubble., 18

The positivity of both reporting and forecasting declined considerably during the market crash in the autumn of 1845 , when much of the coverage focused on share price declines and the negative attitude of The Times to the railways. ${ }^{19}$ As share prices steadied,

\footnotetext{
${ }^{13}$ Railway Times, March 1, 1845, p.280

${ }^{14}$ Railway Times, June 29, 1844, p. 713

${ }^{15}$ Railway Times, October 19, 1844, p.1204

${ }^{16}$ Railway Times, February 1, 1845, pp. 127-128

${ }^{17}$ Railway Times, August 2, 1845, p.1161

${ }^{18}$ Railway Times, March 15, 1845, p.362

${ }^{19}$ Railway Times, Editorials from October 18, 1845 - December 13, 1845, pp. 1962, 2057, 2137, 2185, 2233, 2281, 2313, 2345 and 2377
} 
the tone of reporting generally increased again, and by August 1846 the Railway Times argued that the 'worst is past" ${ }^{20}$. However, with the onset of the economic difficulties in 1847 which were associated with the Commercial Crisis, positivity declined once more.

The positivity of the Economist's railway supplement seems to be fairly independent of stock market changes, except for the substantial decline in positivity which occurred in the autumn of 1845 when railway share prices fell dramatically, as shown in Panel B of Figure 2. At this time it commented on the 'Crisis in the Share Market' and was keen to distinguish between the dividend-paying lines and the riskier projects which had yet to be constructed ${ }^{21}$. The Economist had consistently been wary of speculation in such projects and during the market crash they maintained that such companies 'cannot be, under any circumstances, worth a premium'. ${ }^{22}$ As time progressed, the railway supplement became more focused on reporting events such as company meetings, and gave less editorial comment.

The front page of the Economist made little mention of movements in the stock market, or on individual firms, but it did comment extensively on economic changes which could have affected the financial performance of the railways and other companies. The changes in positivity, shown in Panel B of Figure 3, illustrate the concerns about the economy which arose in the autumn of 1845 , and the problems which occurred in 1847 related to the Commercial Crisis. The timing of these declines suggests that at least some of the changes in railway share prices may have been related to changes in the economy.

\section{Did the railway press affect the market?}

To gauge whether the coverage of the Railway Times, or the Economist's front page or railway supplement had an effect on the aggregate market for railway stocks, we incorporate measures on the amount and positivity of railway coverage into a time series model. For the

\footnotetext{
${ }^{20}$ Railway Times, August 1, 1846, p.1058

${ }^{21}$ Economist, November 8, 1845, p.1109

${ }^{22}$ Economist, November 8, 1845, p.1109
} 
first approach to quantifying media articles, using the LIWC software, and similar to Tetlock (2007), we use an autoregressive distributive lag (ADL) regression to incorporate the media variables into a model of stock returns with multiple lagged values to capture the inertia and delay present in the market. Four lags of each variable are included, meaning that changes in one variable can have an impact on another variable up to one month later. We include past returns of both the railway index and the non-railway index, and the media variables of word count and positive content as shown in Equation 1, with the results reported in Table 4.

RailReturn $_{t}=\alpha_{1} L \tau\left(\right.$ RailReturn $\left._{t}\right)+\gamma_{1} L \tau\left(\right.$ NonrailReturn $\left._{t}\right)+\gamma_{2} L \tau\left(\right.$ WordCount $\left._{t}\right)+\gamma_{3}$ L $\left(\right.$ Positive $\left._{t}\right)$

where $L \tau$ is a lag operator; RailReturn ${ }_{t}$ is the weekly value-weighted return on the index of railway stocks in week $\mathrm{t}$; NonrailReturn $n_{t}$ is the weekly value-weighted return on the index of non-railway stocks in week t; WordCount $t_{t}$ is the total number of words published in week t; and Positive $_{t}$ is the mean article positivity score for week $\mathrm{t}$ from LIWC. We run separate Newey-West regression models for each publication for the period 1843 to $1850^{23}$

For the second approach to quantifying media content, using subjective assessment, we run a similar model but use different media variables, by including the measures of how positive the reporting and forecasting in each publication was, as shown in Equation 2, with the results reported in Table 5.

RailReturn $_{t}=\alpha_{1} L \tau\left(\right.$ RailReturn $\left._{t}\right)+\gamma_{1} L \tau\left(\right.$ NonrailReturn $\left._{t}\right)+\gamma_{2} L \tau\left(\right.$ Reporting $\left._{t}\right)+\gamma_{3}{\text { L } \tau\left(\text { Forecast }_{t}\right)}$

where $L \tau$ is a lag operator; RailReturn $_{t}$ is the weekly value-weighted return on the index of railway stocks in week t; NonrailReturn ${ }_{t}$ is the weekly value-weighted return on the index of non-railway stocks in week t; Reporting is a subjective assessment of how positive the reporting of recent events was in week t; and Forecast $t_{t}$ is a subjective assessment of how

\footnotetext{
${ }^{23}$ The results using this approach for the sub-period between October 1843 and October 1847 are consistent with the main results from 1843 to 1850 .
} 
positive the forecasting of the future was in week t. We run separate Newey-West regression models for each publication for the four years around the market peak, namely October 1843 to October 1847.

\section{$<<$ INSERT TABLES 4 and 5>>}

From the various specifications shown in Tables 4 and 5, we find several key results. Firstly, there is evidence that changes in the stock market affected media sentiment. For the Railway Times, it appears that changes in both railway returns and non-railway returns affected how positive the content of editorials were in subsequent weeks (Column 4 of Table 4), and that non-railway returns affected the positivity of reporting (Column 3 of Table 5). Similarly, for the front page of the Economist, non-railway returns affected the positivity of content (Column 12 of Table 4) and the positivity of reporting (Column 11 of Table 5). These findings suggest that events in the stock market and economy may have affected the tone of media coverage. This can be seen most clearly around the time of the market crash in October 1845. Before the crash, the Railway Times remained confident about the market, but in the weeks after share prices started to fall, the editorials were forced to comment on the 'depression' in railway shares. These articles were defensive in tone about the prospects of the railway industry, and were extremely hostile to parties such as The Times whom they blamed for bearing the market. ${ }^{24}$ Similarly, the economic problems which occurred at this time, and which affected non-railway returns, led to less positive comment by both the Railway Times and the front page of the Economist.

Secondly, the reporting of recent events by the media may have affected stock returns. For the Railway Times, there is a suggestion that positive reporting of what had already happened resulted in higher railway stock returns in subsequent weeks (Column 1 of Table 5). This finding may also be supported by the evidence that changes in the amount of

\footnotetext{
${ }^{24}$ Railway Times, Editorials from October 18, 1845 - December 13, 1845, pp. 1962, 2057, 2137, 2185, 2233, 2281, 2313, 2345 and 2377
} 
coverage, in both the Railway Times and the Economist's railway supplement, affected railway stock returns (Columns 1 and 5 of Table 4). Weeks when there was a lot of railwayrelated news (and hence increased word count) may have been followed by larger changes in stock prices as investors responded to the new information.

Thirdly, there is no evidence that positive sentiment, as measured either by the LIWC software, or from a subjective assessment of forecasts, played any role in hyping railway stocks. For the Railway Times, the publication which had the strongest motive to hype stocks due to its reliance on advertising by railway companies, and which could potentially have had the biggest impact on railway returns due to its large circulation amongst railway investors, both the positive content measure (Column 1 of Table 4) and the forecasting measure (Column 1 of Table 5) are insignificant in explaining railway stock returns. Indeed, the lags of the forecasting measure have negative coefficients, suggesting that if there was any relationship, it was the opposite of what may have been expected from hyping. The Railway Times may have tried to maintain confidence in the future of the railway market, but this was unsuccessful and railway stock prices continued to fall. This conclusion may also be supported by the negative and significant coefficients which suggest that more positive content was followed by lower non-railway returns (Column 2 of Table 4), implying that economic conditions continued to deteriorate following positive editorials by the Railway Times. There is some suggestion that the positivity of the Economist's railway supplement may have had an impact on railway stock returns (Column 5 of Table 4), but the sign of the coefficients are inconclusive as to whether there was a positive or negative relationship. There is also no evidence that the sentiment of the front page of the Economist, or its forecasts, had any effect on railway stock returns (Column 9 of Table 4 and Column 9 of Table 5). 
This section has focused on the long-term relationship between the railway press and the market for railway stocks. Our results suggest that the media may have been affected by stock returns, and that media reporting of recent events may have had an influence on stock prices. However, of most interest is the finding that the sentiment of the media had no impact in hyping railway stock prices, and cannot be blamed for exacerbating the Mania for investing in railway shares.

\section{Editorials of mainstream press and the bearing of the market}

Between 1843 and 1850, there were 39 weeks in which The Times published editorials concerning railways. The initial articles during the boom tended to focus on the operation of the government's Railway Department of the Board of Trade, which advised Parliament on sanctioning new railway proposals. However, it issued its first alarm about the market for railway shares on July 1,1845 , four months prior to the market crash. It was concerned that too many railways were being promoted, and that subscribers to those schemes would be unable to pay the capital which would be required for construction. It began and ended its article with the question 'whence is to come all the money for the construction of the projected railways? 25 From this point on, The Times adopted a consistently hostile attitude to railway schemes. The Railway Times argued that the antagonistic stance of The Times was responsible for the downturn, and for nine consecutive weeks, the Railway Times' lead article was focused on attacking The Times for bearing the market ${ }^{26}$.

Four weeks after the onset of the market crash, on November 17, as railway share prices continued to fall, The Times published a special supplement detailing the amount of capital which would be required by the 1,263 new railway schemes which were being promoted. During the downturn, The Times continued to be critical of railways on topics

\footnotetext{
${ }^{25}$ The Times, July 1, 1845, p.4

${ }^{26}$ Railway Times, Editorials from October 18, 1845 - December 13, 1845, pp. 1962, 2057, 2137, 2185, 2233, 2281, 2313, 2345 and 2377
} 
such as the progress of railway bills seeking authorisation, the raising of capital by railway companies, and the audit of railway accounts.

The Economist published 16 front page editorials which discussed railways extensively. The particular subject of each article varied throughout the course of the period, but the tone was consistently cautious, and generally negative, regarding railway share prices and the promotion of new railway schemes. The Economist also discussed concerns about the effects of the payments of deposits on new railway projects on October 4,1845 , just a few weeks prior to the market crash. ${ }^{27}$ During this week, the Economist also began publication of its Railway Monitor supplement, which started with an extensive and detailed critique of the negative effects which the new railways would have. Throughout the downturn, the Economist published numerous articles on the effects of the diversion of capital to the railways from other industries, the extent of railway liabilities from lines which had been authorised but which had not been constructed, and the discovery of fraud in the accounts of some railways. Although admitting the long-term benefits of the railway industry, these articles generally raised concerns about various aspects of railway finance.

To determine if the editorials of The Times or the Economist had any impact on railway share prices, the return of an index of all railway shares has been calculated for the week subsequent to each editorial's publication. The mean and standard error of these returns were then measured, and a t-statistic calculated. Table 6 shows that in the week when a railway editorial was published in The Times, the mean return was $0.38 \%$, and for the Economist there was also an increase of $0.38 \%$. This suggests that railway share prices continued to increase despite the commentary by these newspapers.

\section{$<<$ INSERT TABLE 6 >>}

\footnotetext{
${ }^{27}$ Economist, October 4, 1845, p.1
} 
To analyse the robustness of these findings, alternative variations of the event study were considered. To control for changes in the broader market, the return of the 22 largest non-railway firms was also estimated. The mean excess return of the railway index minus the non-railway index in the week of an editorial was $0.39 \%$ for The Times, and $0.54 \%$ for the Economist. The excess return of the railway index above the risk-free rate, measured by the yield on Consols, which were government debt perpetuities, was $0.31 \%$ and $0.32 \%$ for The Times and the Economist respectively.

A fourth approach estimated the relationship between the railway industry and the rest of the market, and used this relationship to predict the expected return of the railway industry during a particular week. The beta of the railway industry was calculated by regressing the weekly return of the railway index against the return of the non-railway index over the period 1843-1850. This beta, multiplied by the non-railway index, was then used to estimate the expected return for the event study. The excess return using this measure was $0.51 \%$ for The Times and $0.69 \%$ for the Economist. A variation on this approach, which used a thin-trading beta as per Dimson (1979), produced a similar finding. All of the results in Table 6 suggest that although The Times and the Economist published particularly negative commentary on the railway industry, railway share prices continued to increase.

Extending the event window does not change the key results. Figure 4 plots the average returns around the publication date when all editorials are considered, and shows that for several weeks prior to publication, and immediately afterwards, railway share prices were increasing. Share prices tended to fall two weeks after the Economist editorials, but the cumulative returns after four weeks were not significantly different from zero.

\section{$<$ INSERT FIGURE 4 >>}

These findings suggest that the negativity of The Times and the Economist did not have an immediate impact in that they did not curtail or end the Mania. This is consistent 
with the observation that railway share prices continued to increase during the summer of 1845 , even when the scepticism of the mainstream media was already clear. It could be argued that the articles issued by The Times and the Economist in October 1845 had a unique impact, compared to earlier or later editorials. However, they were generally restating arguments which had already been made up to five months before. A more likely explanation is that these October editorials simply coincided with changes in other variables which were the true cause of the crash. Contemporaneous with these editorials, there was the onset of an agricultural crisis, and an unprecedented increase in the promotion of new railway schemes, both of which could have affected investor expectations.

\section{Media coverage of individual stocks}

The analysis thus far has focused on whether the tone of media coverage had an impact on stock returns. However, it is also possible that the extent of coverage may also have played a role, as a stock which receives more attention may be more sought after by investors (Barber and Odean, 2008). In this section, we test whether the amount of media coverage received by individual companies influenced the returns on their stocks. If some stocks have been hyped, we might expect stocks with more coverage to have higher returns. Alternatively, if some stocks have substantial media coverage, they may have a lower return as the media may act as an information disseminator for such stocks (Fang and Peress, 2009).

To analyse this issue, the Railway Times and the Economist's railway supplement have been examined to determine the extent of coverage of individual stocks. Each of the 34,264 columns in the Railway Times and the 1,022 columns of the Economist's railway supplement was converted into text using OCR software, and the resultant output was then searched for the names of all of the railway companies which were listed on the London stock exchange at any time during the period 1843 to 1850. 
Table 7 presents summary statistics on an annual basis for the amount of coverage in the cross-section of stocks. An examination of coverage in the Railway Times, excluding the share price tables, suggests that an average of $85.1 \%$ of stocks were mentioned each year. For the Economist's railway supplement, coverage was generally lower, but still $68.3 \%$ of stocks were mentioned. For those companies which received some coverage, the number of columns in which they were mentioned varied widely, from a minimum of just one, to a maximum of 4,810 columns for the Great Western Railway (one of the largest railways at the time), which represented $14.0 \%$ of all columns.

\section{$<$ INSERT TABLE $7>$}

The Fama and MacBeth (1973) regression analysis reported in Table 8 relates the total number of columns in which a particular stock was mentioned each year, to other variables for that firm, such as size, the par/price ratio (a proxy for the book/market ratio), annual return, and absolute annual return. The results suggest that size had a highly significant relationship with the extent of media coverage, whilst the absolute annual return was also a factor. This is consistent with the expectation that larger firms, and those with more volatile returns, were mentioned most often.

\section{$<<$ INSERT TABLE 8 >>}

The extent of media coverage for each railway was then measured by the number of columns in which that railway had been mentioned within a particular month. To analyse whether media coverage had an impact on returns, each stock was assigned to one of three portfolios each month, in an approach similar to Fang and Peress (2009). No-media-coverage firms were those which were not mentioned at all. The median number of columns of the remaining sample was then calculated for each month. Low-coverage stocks were defined as those which were below the median, whilst extensive-coverage stocks had above median coverage. 
The monthly return of each stock was calculated as the change in the log of price, controlling for changes in capital (as measured by changes in the par value of the stock). The return in the subsequent month was calculated for each portfolio, by using a weighted average of returns for the individual companies within that portfolio. Only companies which traded during a particular month were included, resulting in a total of 5,667 observations. Market indices were then constructed from these monthly returns. As can be seen from Figure 5, for most of the sample period, extensive-media-coverage firms outperformed lowcoverage firms, which themselves outperformed no coverage firms.

\section{$<$ INSERT FIGURE 5 >>}

To analyse the significance of these differences, the average across time of each portfolio's monthly returns was then calculated. A $t$-test was performed to determine if there was a significant difference in returns between extensive and no-media-coverage firms. Table 9 suggests that no-media-coverage firms earned significantly lower returns overall.

\section{$<$ INSERT TABLE 9 >}

This analysis was then performed on various sorts of the data, by allocating firms into portfolios based on their size, book/market value, current return, previous return, price and liquidity. Size was measured by market capitalisation, book/market value by the par/price ratio, current return and previous return by the change in the log of the price for a given month, price by the last traded share price, and liquidity by the number of days during the month that a stock had traded.

For each variable, each company was ranked, and then allocated into one of three categories, with category zero being the lowest, and category two being the highest in each instance. ${ }^{28}$ As can be seen from Table 9, when the analysis of no-minus-extensive-mediacoverage returns is performed on these subsamples, the difference is significant at the five

\footnotetext{
${ }^{28}$ The number of observations in each category is shown in Appendix Table 1.
} 
percent level in 12 of the 54 tests (five for the overall period, one for the boom and six for the downturn). 10 out of the 12 significant differences suggest that no-media-coverage firms earned lower returns than extensive-media-coverage firms.

However, this analysis does not control for other risk factors. Fang and Peress (2009) suggest calculating the returns of a portfolio which is long on no media coverage stocks and short on extensive media coverage stocks, which we refer to as No Minus Extensive (NME). The returns on this portfolio are then regressed against the market return minus the risk-free rate, and returns on a portfolio which is long on small stocks and short on big stocks (SMB), a portfolio which is long on high book/market stocks and short on low book/market stocks (HML), and a portfolio which is long on illiquid stocks and short on the most liquid stocks (IMM). The constant from this regression reveals the size and significance of the returns on the NME portfolio after controlling for other risk factors, which will indicate whether there was a premium on extensive-media-coverage firms after other factors have been considered.

To pursue this analysis for the Railway Mania, the ranking and categorisation of companies, discussed above with regards to Table 9, was repeated and the NME portfolio was calculated by subtracting the returns in the subsequent month for extensive-mediacoverage stocks from those on no-coverage stocks. Similarly, the SMB portfolio was constructed by subtracting the returns in the next month for large stocks from those on small, the HML portfolio was estimated by subtracting the return in the following month for high book/value stocks from those with a low book/value, and the IMM portfolio was formed by subtracting the returns in the next month for the most liquid stocks from illiquid stocks.

The regression results shown in Table 10 indicate that none of the risk factors had a significant relationship with the NME portfolio during the boom. The constant from these regressions are also insignificant, which implies that there was no significant difference between no-media and extensive-media stocks, once the other characteristics of these firms 
have been controlled for. For the downturn, and for the period as a whole, there was a significant positive relationship between SMB and NME, and a significant negative relationship between HML and NME. However, the constant is not significant in any of these specifications, indicating that there was not a significant difference in returns for the NME portfolio after risk factors have been controlled for.

$$
<<\text { INSERT TABLE 10>> }
$$

These results suggest that although more extensive media coverage firms earned higher returns during the boom phase of the Railway Mania, and lower returns during the downturn, this was largely due to differences in the characteristics of those firms, rather than the actual volume of media coverage.

Overall, the findings of this section suggest that high-media-coverage stocks earned higher returns than stocks with no media coverage, but that risk factors accounted for this difference. This finding differs from that for the modern US market as documented by Fang and Peress (2009), who find that there is a premium for no-media-coverage stocks. This difference between their study and ours may arise because no-media-coverage railways were small local companies, which raised their capital from investors in the immediate locality (Broadbridge, 1968, p.193). Consequently, investors had sufficient information on the stocks of these companies, and there was no need for a no-media-coverage premium.

Perhaps of more interest with regards the relationship between the media and a bubble, the results also imply that individual stocks were not successfully hyped by the media. Although those firms which received the most coverage tended to earn higher returns, this was due to standard risk factors, and not due to a psychological bias on the part of investors which could have led to certain stocks being more sought after simply because they received more attention. 


\section{Role of the Media during the Mania}

Our findings above suggest that the media did not play a major role in driving investor sentiment during the Mania. This is consistent with the argument of Campbell (2012), that the asset price reversal during the Railway Mania was driven by changes to future cash flows and ultimately dividends. As can be seen from Figure 6, during the boom phase of the Mania, railways increased their dividends. Although dividends remained high for about 18 months after the fall in railway stock prices commenced, they began to decrease steadily from 1847 onwards, falling from a high of seven percent in 1847 to three percent by 1850 .

The collapse of the market for railway shares in October 1845 may have occurred because investors began to realise that dividends would not remain at high levels in the longer term. The immediate signal which may have led them to revise their expectations was the onset of a poor agricultural harvest, which threatened economic growth, and the dramatic rise in the promotion of new railway schemes in the late summer and early fall of 1845 , which followed the abolition of the Railway Board in July 1845, whose task it had been to ration railway charters. The word count of adverts which ran in the Railway Times can be regarded as a measure of promotional activity, as the vast majority of adverts at this time were aimed at attracting subscribers to invest in new railway schemes, and as can be seen from Figure 7, the promotion of new railway companies spiked sharply in the fall of 1845 . This rapid expansion threatened the profitability of the railway industry as many of these companies were going to compete with existing railway lines. When investors foresaw that competition from new railways would diminish future cash flows and ultimately the dividends of existing railways, the market for railway stocks crashed.

\section{$<<$ INSERT FIGURES 6 \& 7>>}

What role did the media play in this explanation for the Mania? Although the media may not have hyped the Mania, in the absence of other channels, it most definitely played a 
role in disseminating fundamental information in the form of company and parliamentary reports to investors. As can be seen from Table 2, nearly half of the content in the average issue of the Railway Times was in the form of company and parliamentary reports. In other words, the railway periodicals laid facts before investors, which enabled them to estimate the future cash flows of railway companies.

The media also played a role through advertising new railway schemes and by enabling promoters to reach a disparate group of individuals seeking outlets for their savings. These adverts were essentially short prospectuses, detailing the proposed route for a new railway line, the local businessmen and gentry who supported the scheme, the financial and public advantages which would result, and an application form which would allow interested readers to subscribe for shares. As can be seen from Table 2, the adverts placed by railway promoters constituted a substantial proportion of the content of the Railway Times, with over half of the total content in 1845 consisting of such adverts. ${ }^{29}$ It is possible that by allowing new railway projects to provide such information, and by making it easy to invest in new schemes, the media indirectly facilitated the promotion boom in new railway lines.

\section{Conclusion}

Media coverage of the market for railway stocks grew during the boom phase of the British Railway Mania and declined shortly after the market peak. However, we find no evidence of the railway press hyping their reporting. This finding may be consistent with Gentzkow and Shapiro (2006) as the lack of hype may be attributable to the intense competition in the market for railway periodicals and the sources of ex post news verification in the form of The

\footnotetext{
${ }^{29}$ A positivity measure was not estimated for adverts as new railway companies tended to promote themselves by providing long lists of prominent businessmen and nobility who were supporting the schemes. These names are regarded as neutral from a linguistic viewpoint so the measure of positivity does not entirely capture the nature of the adverts. Another difficulty is that although the sample size of advertising is very large during the peak in prices, it is very small at the very beginning and end of the period, so the mean may more easily be biased.
} 
Times and other constituents of the national press. Reader (and investor) heterogeneity may also have contributed to the lack of bias or hype (Mullainathan and Shleifer, 2005).

Our evidence suggests that the media did not play a major role in propagating (or bringing to an end) one of the 'greatest bubbles in history'. The editorial content of the railway specific media did not boost stock returns during the boom, and the opinion pieces of The Times and the Economist did not cause the market crash. Although those companies which received greater coverage also experienced a greater price reversal, this was primarily due to other risk factors. The media may have played some role in the Mania by disseminating information, but it had little influence on investors via its editorial opinion pieces.

\section{References}

Akerlof, G.A., Shiller, R.J., 2009. Animal Spirits. Princeton University Press, Princeton.

Barber, B.M., Odean, T., 2008. All that glitters: the effect of attention and news on the buying behavior of individual and institutional Investors. Review of Financial Studies 21 (2), 785-818.

Baskin, J.B., Miranti, P.J., 1997. A History of Corporate Finance. Cambridge University Press, Cambridge.

Bhattacharya, U., Galpin N., Ray, R., Yu, X. 2009. The role of the media in the Internet IPO. Journal of Financial and Quantitative Analysis 44 (3), 657-82.

Bignon, V., Miscio, A., 2010. Media bias in financial newspapers: evidence from early twentieth-century France. European Review of Economic History 14, 383-432.

Broadbridge, S.A., 1968. The sources of railway share capital. In M.C. Reed (ed.), Railways in the Victorian Economy: Studies in Finance and Economic Growth. Augustus Kelley, New York, 184-211.

Brown, L., 1985. Victorian News and Newspapers. Clarendon Press, Oxford.

Campbell, G., 2012. Myopic rationality in a mania. Explorations in Economic History 49, 75-91. 
Campbell, G., Turner, J.D. 2012. Dispelling the myth of the naive investor during the British Railway Mania, 1845-46. Business History Review 86, 3-41.

Cheffins, B.R. 2008. Corporate Ownership and Control: British Business Transformed. Oxford University Press, Oxford.

Cutler, D.M., Poterba, J.M., Summers, L.H. 1989. What moves stock prices? Journal of Portfolio Management 15, 4-12.

Dimson, E., 1979. Risk measurement when shares are subject to infrequent trading. Journal of Financial Economics 7, 197-226.

Dougal, C., Engelberg, J., Garcia D., Parsons, C.A., 2012. Journalists and the stock market. Review of Financial Studies 25 (3), 639-79.

Dyck, A., Zingales, L., 2003a. The bubble and the media. In P. Cornelius and B. Kogut (eds.), Corporate Governance and Capital Flows in a Global Economy. Oxford University Press, New York.

Dyck, A., Zingales, L., 2003b. The Media and Asset Prices. HBS Working Paper Series, No. 04-003.

Economist, 2008. The beauty of bubbles: booms and busts. The Economist 389, p.115.

Engelberg, J., Parsons, C.A., 2011. The causal impact of media in financial markets. Journal of Finance 66 (1), 67-97.

Fama, E. F., MacBeth, J., 1973. Risk, return and equilibrium: empirical tests. Journal of Political Economy 81, 607-636.

Fang, L., Peress, J., 2009. Media coverage and the cross-section of stock returns. Journal of Finance 64 (5), 2023-52.

Francis, J., 1851. A History of the English Railway: Its Social Relations and Revelations. 1820-1845. Brown, Green, and Longmans, Longman, London.

Gayer, A.D., Rostow, W.W., Jacobson Schwartz, A., 1953. The Growth and Fluctuation of the British Economy. Clarendon Press, Oxford.

Gentzkow, M., Shapiro, J.M., 2006. Media bias and reputation. Journal of Political Economy 114 (2), 280-316.

Huberman, G., Regev, T., 2001. Contagious speculation and a cure for cancer: a nonevent that made stock prices soar. Journal of Finance 56 (1), 387-96.

Hyndman, H.M., 1892. Commercial Crises of the Nineteenth Century. Augustus M. Kelley, New York.

Kindleberger, C.P., 1984. A Financial History of Western Europe. George Allen and Unwin, London. 
Kostal, R.W., 1994. Law and English Railway Capitalism. Clarendon Press, Oxford.

Lewin, H.G., 1936. The Railway Mania and its Aftermath. David \& Charles, Newton Abbot.

Loughran, T., McDonald, B., 2011. When is a liability not a liability? Textual analysis, dictionaries, and 10-Ks. Journal of Finance 66, 35-65.

Mackay, C.,1856. Memoirs of Extraordinary Popular Delusions and the Madness of Crowds, 3rd Edition. G. Routledge and Co., London

Mitchell, B.R., 1964. The coming of the railway and United Kingdom economic growth. Journal of Economic History 24 (3), 315-66.

Mullainathan, S., Shleifer, A., 2005. The market for news. American Economic Review 95 (4), 1031-53.

North, J.S., 1997. The Waterloo Directory of English Newspapers and Periodicals 18001900. Waterloo Academic Press, Waterloo.

Parliamentary Papers, 1845. Return of Railway Subscribers, XL. House of Commons, London.

Parliamentary Papers, 1846. Return of Railway Subscribers, XXXVIII. House of Commons, London.

Parliamentary Papers, 1852. Return of the Number of Newspaper Stamps at One Penny, XLII. House of Commons, London.

Preda, A., 2001. The rise of the popular investor: financial knowledge and investing in England and France, 1840-1880. The Sociological Quarterly 42 (2), 205-32.

Reuter, J., Zitzewitz, E., 2006. Do ads influence editors? Advertising and bias in the financial media. Quarterly Journal of Economics 121 (1), 197-227.

Simmons, J., 1978. The Railway in England and Wales, 1830-1914, vol.1. Leicester University Press, Leicester.

Simmons, J., 1991. The Victorian Railway. Thames and Hudson, London.

Shiller, R.J., 2005. Irrational Exuberance, 2nd Edition. Princeton University Press, Princeton, NJ..

Taylor, J., 2012. Watchdogs or apologists? Financial journalism and company fraud in early Victorian Britain. Historical Research (forthcoming).

Tetlock, P.C., 2007. Giving content to investor sentiment: the role of media in the stock market. Journal of Finance 62 (3), 1139-68. 
Tetlock, P.C., 2010. Does public financial news resolve asymmetric information? Review of Financial Studies 23 (9), 3520-57. .

Tuck, H., 1846. The Railway Shareholder's Manual; Or Practical Guide to All the Railways in the World, 7th Edition, Effingham Wilson, London. 
Table 1. Leading London Newspapers and Periodicals in the 1840s

\begin{tabular}{lcccc}
\hline \hline & Established & Frequency & $\begin{array}{c}\text { 1845 circulation } \\
\text { (est) }\end{array}$ & $\begin{array}{c}\text { 1850 circulation } \\
\text { (est) }\end{array}$ \\
& & & & \\
The Times & 1785 & Daily & $8,100,000$ & $11,900,000$ \\
Morning Herald & 1780 & Daily & $2,018,025$ & $1,139,000$ \\
Morning Chronicle & 1769 & Daily & $1,554,000$ & 912,547 \\
Lloyds Weekly London & 1842 & Weekly & $2,777,432$ & $2,559,000$ \\
Illustrated London News & 1842 & Weekly & $2,532,010$ & $3,467,007$ \\
Railway Times & 1837 & Weekly & 355,350 & 85,700 \\
Herepath's Railway Journal & 1835 & Weekly & 234,500 & 98,300 \\
Railway Record & 1844 & Weekly & 186,500 & 31,750 \\
Economist & 1843 & Weekly & 150,500 & 199,000 \\
& & & & \\
\hline \hline
\end{tabular}

Sources: The circulation data is from Parliamentary Papers (1852) and is based on the one penny stamp duty paid on each copy of the newspaper which was published. The date of establishment is from North (1997). 
Table 2. Average Weekly Breakdown of Railway Times Content

\begin{tabular}{cccccc}
\hline \hline & Adverts & $\begin{array}{c}\text { Company and } \\
\text { parliamentary reports } \\
(\%)\end{array}$ & $\begin{array}{c}\text { Letters from } \\
\text { readers } \\
(\%)\end{array}$ & Editorial & Word count \\
\hline 1843 & 15.0 & 42.5 & 19.4 & 23.1 & $46,256.7$ \\
1844 & 31.8 & 43.5 & 8.2 & 16.4 & $53,841.8$ \\
1845 & 54.9 & 33.1 & 4.1 & 7.9 & $81,787.8$ \\
1846 & 23.6 & 57.5 & 6.1 & 12.8 & $65,551.9$ \\
1847 & 19.1 & 57.3 & 7.8 & 15.9 & $53,391.9$ \\
1848 & 16.5 & 54.0 & 11.8 & 17.8 & $43,832.0$ \\
1849 & 14.1 & 62.9 & 7.2 & 15.8 & $42,003.1$ \\
1850 & 12.0 & 59.0 & 9.5 & 19.5 & $40,538.5$ \\
$1843-50$ & 26.3 & 49.8 & 8.6 & 15.2 & $53,477.2$ \\
\hline \hline
\end{tabular}

Notes: Each column within the Railway Times was manually categorised according to its content. Optical Character Recognition (OCR) was then used to generate text files which were fed into the Linguistic Inquiry and Word Count (LIWC) software to produce the word count of articles from each section of the periodical. 
Table 3. Descriptive Statistics for Scale and Positivity of Media Coverage, 1843-50

\begin{tabular}{lccccccc}
\hline \hline \multicolumn{7}{c}{ Panel A: Railway Times News and Editorial section } \\
\hline \multicolumn{7}{c}{ Positive words (\%) } \\
\hline 1843 & Mean & Median & Std. Dev. & Max. & Min. & Mean & Median \\
1844 & 10.2 & 10.1 & 0.9 & 12.0 & 8.1 & $10,705.6$ & $10,803.0$ \\
1845 & 11.0 & 10.9 & 1.2 & 13.7 & 8.7 & $8,834.3$ & $9,171.5$ \\
1846 & 11.6 & 11.7 & 1.5 & 14.7 & 7.8 & $6,430.7$ & $6,357.0$ \\
1847 & 11.4 & 11.3 & 1.3 & 14.0 & 8.7 & $8,410.6$ & $7,766.0$ \\
1848 & 10.7 & 10.8 & 1.2 & 13.6 & 8.0 & $8,474.5$ & $6,741.0$ \\
1849 & 10.3 & 10.5 & 1.4 & 12.9 & 7.2 & $7,800.8$ & $6,824.0$ \\
1850 & 10.8 & 10.9 & 1.2 & 13.0 & 7.8 & $6,638.0$ & $6,207.5$ \\
$1843-50$ & 11.6 & 11.6 & 1.4 & 14.9 & 8.8 & $7,905.2$ & $7,409.5$ \\
\hline
\end{tabular}

Panel B: Economist's Railway Supplement

\begin{tabular}{lccccccc}
\hline & \multicolumn{4}{c}{ Positive words (\%) } & \multicolumn{2}{c}{ Word count } \\
\hline & Mean & Median & Std. Dev. & Max. & Min. & Mean & Median \\
\hline 1845 & 14.5 & 13.7 & 3.5 & 25.8 & 8.4 & $3,055.1$ & $1,088.0$ \\
1846 & 12.1 & 11.8 & 1.5 & 15.7 & 9.0 & $7,032.6$ & $6,332.0$ \\
1847 & 12.0 & 12.3 & 2.7 & 19.6 & 6.8 & $3,189.4$ & $2,432.0$ \\
1848 & 13.6 & 13.0 & 3.3 & 31.0 & 9.2 & $2,163.8$ & $1,682.0$ \\
1849 & 14.9 & 14.6 & 3.9 & 29.7 & 7.9 & 947.3 & 747.0 \\
1850 & 16.3 & 15.7 & 4.3 & 29.5 & 8.2 & 737.5 & 669.0 \\
$1845-50$ & 13.9 & 13.2 & 3.6 & 31.0 & 6.8 & $2,854.7$ & $1,389.5$ \\
\hline
\end{tabular}

Panel C: Economist's Front Page

\begin{tabular}{lccccccc}
\hline & \multicolumn{3}{c}{ Positive words (\%) } & & \multicolumn{2}{c}{ Word count } \\
\hline 1843 & Mean & Median & Std. Dev & Max. & Min & Mean & Median \\
1844 & 10.3 & 10.1 & 1.8 & 13.8 & 7.4 & $4,051.1$ & $3,616.5$ \\
1845 & 11.0 & 10.5 & 1.8 & 15.8 & 7.5 & $4,246.3$ & $3,685.5$ \\
1846 & 10.5 & 10.4 & 2.1 & 15.3 & 5.2 & $3,650.8$ & $3,455.0$ \\
1847 & 10.0 & 10.0 & 2.2 & 13.7 & 5.1 & $3,745.5$ & $3,415.0$ \\
1848 & 10.4 & 10.5 & 1.7 & 14.5 & 7.6 & $4,277.2$ & $3,559.0$ \\
1849 & 10.7 & 10.6 & 1.8 & 15.0 & 7.1 & $4,213.9$ & $3,386.0$ \\
1850 & 10.7 & 10.8 & 2.0 & 14.6 & 6.6 & $3,753.9$ & $3,391.0$ \\
$1843-50$ & 10.7 & 10.4 & 2.3 & 16.8 & 6.8 & $4,137.0$ & $3,360.5$ \\
\hline \hline
\end{tabular}

Notes: Word count calculated using Linguistic Inquiry and Word Count (LIWC). Positive content is the percentage of positive words in an article divided by the total psychological processes word count as classified by LIWC's in-built dictionary. 
Table 4. Newey-West Regressions of Quantitative Measures of Media Coverage and Stock Market Performance, 1843 to 1850

\begin{tabular}{|c|c|c|c|c|c|c|c|c|c|c|c|c|}
\hline & \multicolumn{4}{|c|}{ Railway Times } & \multicolumn{4}{|c|}{ Economist Railway Monitor } & \multicolumn{4}{|c|}{ Economist Front Page } \\
\hline & $\begin{array}{c}\text { Railway } \\
\text { Return } \\
(1) \\
\end{array}$ & $\begin{array}{c}\text { Non-Rail } \\
\text { Return } \\
(2) \\
\end{array}$ & $\begin{array}{c}\text { Word Count } \\
\text { (3) } \\
\end{array}$ & $\begin{array}{c}\text { Positive } \\
\text { Content } \\
(4) \\
\end{array}$ & $\begin{array}{l}\text { Railway } \\
\text { Return } \\
(5) \\
\end{array}$ & $\begin{array}{c}\text { Non-Rail } \\
\text { Return } \\
(6) \\
\end{array}$ & $\begin{array}{c}\text { Word Count } \\
\text { (7) } \\
\end{array}$ & $\begin{array}{c}\text { Positive } \\
\text { Content } \\
(8) \\
\end{array}$ & $\begin{array}{c}\text { Railway } \\
\text { Return } \\
(9) \\
\end{array}$ & $\begin{array}{c}\begin{array}{c}\text { Non-Rail } \\
\text { Return } \\
(10)\end{array} \\
\end{array}$ & $\begin{array}{c}\text { Word Count } \\
(11) \\
\end{array}$ & $\begin{array}{c}\text { Positive } \\
\text { Content } \\
(12) \\
\end{array}$ \\
\hline Railway Return ${ }_{t-1}$ & $\begin{array}{c}0.193 * * * \\
(0.053)\end{array}$ & $\begin{array}{c}0.052 * * * \\
(0.015)\end{array}$ & $\begin{array}{l}-0.131 \\
(0.812)\end{array}$ & $\begin{array}{c}0.055 \\
(0.042)\end{array}$ & $\begin{array}{c}0.160 * * * \\
(0.059)\end{array}$ & $\begin{array}{l}0.032 * \\
(0.017)\end{array}$ & $\begin{array}{l}0.147 \\
(0.638)\end{array}$ & $\begin{array}{c}0.084 \\
(0.125)\end{array}$ & $\begin{array}{l}0.197 * * * * \\
(0.053)\end{array}$ & $\begin{array}{c}0.050 * * * \\
(0.015)\end{array}$ & $\begin{array}{c}0.191 \\
(0.394)\end{array}$ & $\begin{array}{c}0.074 \\
(0.065)\end{array}$ \\
\hline Railway Return $\mathrm{t}_{-2}$ & $\begin{array}{c}0.045 \\
(0.065)\end{array}$ & $\begin{array}{l}-0.004 \\
(0.012)\end{array}$ & $\begin{array}{c}1.013 \\
(0.768)\end{array}$ & $\begin{array}{l}0.077^{*} \\
(0.044)\end{array}$ & $\begin{array}{c}0.060 \\
(0.073)\end{array}$ & 0.000 & $\begin{array}{l}1.320^{*} \\
(0.682)\end{array}$ & $\begin{array}{l}-0.120 \\
(0.090)\end{array}$ & $\begin{array}{c}0.057 \\
(0.066)\end{array}$ & -0.003 & $\begin{array}{l}-0.058 \\
(0.358)\end{array}$ & $\begin{array}{l}-0.029 \\
(0.053)\end{array}$ \\
\hline Railway Return $\mathrm{t}_{-3}$ & $\begin{array}{c}0.076 \\
(0.072)\end{array}$ & $\begin{array}{l}-0.006 \\
(0.018)\end{array}$ & $\begin{array}{c}0.644 \\
(0.877)\end{array}$ & $\begin{array}{c}0.030 \\
(0.034)\end{array}$ & $\begin{array}{c}0.103 \\
(0.078)\end{array}$ & $\begin{array}{l}-0.010 \\
(0.019)\end{array}$ & $\begin{array}{l}-0.951^{*} \\
(0.568)\end{array}$ & $\begin{array}{c}0.039 \\
(0.102)\end{array}$ & $\begin{array}{c}0.090) \\
(0.073)\end{array}$ & $\begin{array}{l}-0.004) \\
-0.017)\end{array}$ & $\begin{array}{l}-0.283 \\
(0.346)\end{array}$ & $\begin{array}{l}-0.064) \\
-0.062)\end{array}$ \\
\hline Railway Return $\mathrm{t}_{-4}$ & $\begin{array}{c}0.094 \\
(0.071)\end{array}$ & $\begin{array}{c}0.018 \\
(0.019)\end{array}$ & $\begin{array}{c}0.227 \\
(0.904)\end{array}$ & $\begin{array}{c}0.047 \\
(0.041)\end{array}$ & $\begin{array}{c}0.120 \\
(0.078)\end{array}$ & $\begin{array}{c}0.018 \\
(0.021)\end{array}$ & $\begin{array}{l}-0.444 \\
(0.493)\end{array}$ & $\begin{array}{c}0.240 * * \\
(0.102)\end{array}$ & $\begin{array}{c}0.114 \\
(0.075)\end{array}$ & $\begin{array}{c}0.010 \\
(0.020)\end{array}$ & $\begin{array}{l}-0.711 \\
(0.454)\end{array}$ & $\begin{array}{l}-0.109 \\
(0.076)\end{array}$ \\
\hline $\begin{array}{l}\chi^{2} \\
\mathrm{p} \text {-value }\end{array}$ & $\begin{array}{l}6.85 * * * \\
(0.000)\end{array}$ & $\begin{array}{l}3.05^{* *} \\
(0.017)\end{array}$ & $\begin{array}{c}0.53 \\
(0.714)\end{array}$ & $\begin{array}{l}3.63 * * * \\
(0.006)\end{array}$ & $\begin{array}{l}6.60 * * * \\
(0.000)\end{array}$ & $\begin{array}{l}1.02 \\
(0.395)\end{array}$ & $\begin{array}{c}1.33 \\
(0.259)\end{array}$ & $\begin{array}{l}1.90 \\
(0.110)\end{array}$ & $\begin{array}{l}7.18 * * * \\
(0.000)\end{array}$ & $\begin{array}{l}3.00 * * \\
(0.019)\end{array}$ & $\begin{array}{c}0.81 \\
(0.522)\end{array}$ & $\begin{array}{c}1.25 \\
(0.290)\end{array}$ \\
\hline Non-Railway Return ${ }_{t-1}$ & $\begin{array}{c}0.164 \\
(0.173)\end{array}$ & $\begin{array}{c}0.085 \\
(0.070)\end{array}$ & $\begin{array}{l}-1.527 \\
(3.938)\end{array}$ & $\begin{array}{l}-0.261 * \\
(0.137)\end{array}$ & $\begin{array}{c}0.133 \\
(0.222)\end{array}$ & $\begin{array}{l}0.157 * * \\
(0.066)\end{array}$ & $\begin{array}{l}-0.223 \\
(2.150)\end{array}$ & $\begin{array}{c}0.067 \\
(0.340)\end{array}$ & $\begin{array}{c}0.121 \\
(0.183)\end{array}$ & $\begin{array}{c}0.091 \\
(0.070)\end{array}$ & $\begin{array}{c}0.018 \\
(1.342)\end{array}$ & $\begin{array}{l}0.440^{* * *} \\
(0.173)\end{array}$ \\
\hline Non-Railway Return $\mathrm{t}_{t-2}$ & $\begin{array}{l}-0.082 \\
(0.192)\end{array}$ & $\begin{array}{c}0.025 \\
(0.059)\end{array}$ & $\begin{array}{c}-7.644 * * \\
(3.087)\end{array}$ & $\begin{array}{c}0.065 \\
(0.146)\end{array}$ & $\begin{array}{l}-0.062 \\
(0.241)\end{array}$ & $\begin{array}{l}-0.033 \\
(0.070)\end{array}$ & $\begin{array}{l}-1.816 \\
(1.387)\end{array}$ & $\begin{array}{c}0.489 \\
(0.322)\end{array}$ & $\begin{array}{l}-0.123 \\
(0.201)\end{array}$ & $\begin{array}{c}0.018 \\
(0.067)\end{array}$ & $\begin{array}{c}1.883 \\
(1.230)\end{array}$ & $\begin{array}{l}-0.300^{*} \\
(0.176)\end{array}$ \\
\hline Non-Railway Return ${ }_{t-3}$ & $\begin{array}{l}-0.246 \\
(0.170)\end{array}$ & $\begin{array}{c}0.049 \\
(0.063)\end{array}$ & $\begin{array}{l}-5.141 \\
(3.812)\end{array}$ & $\begin{array}{l}-0.162 \\
(0.166)\end{array}$ & $\begin{array}{l}-0.442^{*} \\
(0.240)\end{array}$ & $\begin{array}{c}0.054 \\
(0.059)\end{array}$ & $\begin{array}{l}2.750^{*} \\
(1.516)\end{array}$ & $\begin{array}{l}-0.568^{*} \\
(0.336)\end{array}$ & $\begin{array}{l}-0.321 \\
(0.208)\end{array}$ & $\begin{array}{c}0.018 \\
(0.068)\end{array}$ & $\begin{array}{l}-0.402 \\
(1.291)\end{array}$ & $\begin{array}{c}0.244 \\
(0.204)\end{array}$ \\
\hline Non-Railway Return ${ }_{t-4}$ & $\begin{array}{l}-0.251 \\
(0.179)\end{array}$ & $\begin{array}{c}0.047 \\
(0.066)\end{array}$ & $\begin{array}{c}2.874 \\
(2.900)\end{array}$ & $\begin{array}{l}-0.124 \\
(0.108)\end{array}$ & $\begin{array}{l}-0.481 * * \\
(0.242)\end{array}$ & $\begin{array}{l}-0.000 \\
(0.058)\end{array}$ & $\begin{array}{l}-0.056 \\
(1.464)\end{array}$ & $\begin{array}{l}-0.336 \\
(0.349)\end{array}$ & $\begin{array}{l}-0.389^{*} \\
(0.214)\end{array}$ & $\begin{array}{c}0.079 \\
(0.064)\end{array}$ & $\begin{array}{c}1.410 \\
(1.225)\end{array}$ & $\begin{array}{c}0.221 \\
(0.175)\end{array}$ \\
\hline$x^{2}$ & 1.80 & 1.39 & $3.05^{* *}$ & $2.18^{*}$ & $3.72^{* * * *}$ & $2.16^{*}$ & 1.14 & 1.25 & $2.44^{* *}$ & 1.84 & 1.00 & $3.00^{* *}$ \\
\hline $\mathrm{p}$-value & $(0.128)$ & $(0.237)$ & $(0.017)$ & $(0.07)$ & $(0.006)$ & $(0.074)$ & $(0.336)$ & $(0.291)$ & $(0.047)$ & $(0.120)$ & $(0.406)$ & $(0.019)$ \\
\hline Word Count $t-1$ & $\begin{array}{l}0.005^{* * *} \\
(0.002)\end{array}$ & $\begin{array}{l}0.001 * \\
(0.001)\end{array}$ & $\begin{array}{c}0.226 * * * \\
(0.048)\end{array}$ & $\begin{array}{c}-0.004 * * \\
(0.002)\end{array}$ & $\begin{array}{l}-0.006 \\
(0.006)\end{array}$ & $\begin{array}{l}-0.002 \\
(0.002)\end{array}$ & $\begin{array}{c}0.543 * * * \\
(0.063)\end{array}$ & $\begin{array}{l}-0.005 \\
(0.009)\end{array}$ & $\begin{array}{c}0.009 \\
(0.007)\end{array}$ & $\begin{array}{c}0.001 \\
(0.002)\end{array}$ & $\begin{array}{c}0.063 \\
(0.052)\end{array}$ & $\begin{array}{l}-0.002 \\
(0.008)\end{array}$ \\
\hline Word Count $t_{-2}$ & $\begin{array}{c}0.001 \\
(0.003)\end{array}$ & $\begin{array}{c}-0.002 * * \\
(0.001)\end{array}$ & $\begin{array}{c}0.138 * * * \\
(0.051)\end{array}$ & $\begin{array}{l}-0.001 \\
(0.002)\end{array}$ & $\begin{array}{l}-0.019 * * \\
(0.009)\end{array}$ & $\begin{array}{l}-0.002 \\
(0.003)\end{array}$ & $\begin{array}{c}0.268 * * * \\
(0.077)\end{array}$ & $\begin{array}{l}-0.019^{*} \\
(0.010)\end{array}$ & $\begin{array}{c}0.007 \\
(0.006)\end{array}$ & $\begin{array}{l}-0.000 \\
(0.002)\end{array}$ & $\begin{array}{c}0.000 \\
(0.058)\end{array}$ & $\begin{array}{c}0.000 \\
(0.008)\end{array}$ \\
\hline Word Count $t_{-3}$ & $\begin{array}{l}0.006^{* *} \\
(0.002)\end{array}$ & $\begin{array}{l}0.002^{*} \\
(0.001)\end{array}$ & $\begin{array}{l}0.096^{* * *} \\
(0.046)\end{array}$ & $\begin{array}{l}0.004 * \\
(0.002)\end{array}$ & $\begin{array}{c}0.010 \\
(0.009)\end{array}$ & $\begin{array}{c}0.002 \\
(0.002)\end{array}$ & $\begin{array}{c}0.118 \\
(0.074)\end{array}$ & $\begin{array}{l}-0.002 \\
(0.008)\end{array}$ & $\begin{array}{c}0.006 \\
(0.006)\end{array}$ & $\begin{array}{l}-0.001 \\
(0.002)\end{array}$ & $\begin{array}{l}0.129^{* * *} \\
(0.061)\end{array}$ & $\begin{array}{l}-0.006 \\
(0.008)\end{array}$ \\
\hline Word Count $_{\mathrm{t}-4}$ & $\begin{array}{l}-0.002 \\
(0.003)\end{array}$ & $\begin{array}{l}0.000 \\
(0.001)\end{array}$ & $\begin{array}{c}0.062 \\
(0.049)\end{array}$ & $\begin{array}{l}-0.004 * * \\
(0.002)\end{array}$ & $\begin{array}{c}0.009 \\
(0.009)\end{array}$ & $\begin{array}{c}0.000 \\
(0.002)\end{array}$ & $\begin{array}{l}-0.012 \\
(0.098)\end{array}$ & $\begin{array}{c}0.006 \\
(0.007)\end{array}$ & $\begin{array}{l}-0.001 \\
(0.006)\end{array}$ & $\begin{array}{c}0.002 \\
(0.002)\end{array}$ & $\begin{array}{c}0.025 \\
(0.047)\end{array}$ & $\begin{array}{c}0.002 \\
(0.008)\end{array}$ \\
\hline $\begin{array}{l}\chi^{2} \\
\text { p-value }\end{array}$ & $\begin{array}{l}2.49 * * \\
(0.043)\end{array}$ & $\begin{array}{l}2.28^{*} \\
(0.060)\end{array}$ & $\begin{array}{c}17.83 * * * \\
(0.000)\end{array}$ & $\begin{array}{l}3.11 * * \\
(0.015)\end{array}$ & $\begin{array}{l}3.37 * * \\
(0.010)\end{array}$ & $\begin{array}{l}1.48 \\
(0.209)\end{array}$ & $\begin{array}{c}168.85 * * * * \\
(0.000)\end{array}$ & $\begin{array}{l}3.06 * * \\
(0.017)\end{array}$ & $\begin{array}{c}1.17 \\
(0.322)\end{array}$ & $\begin{array}{c}0.30 \\
(0.881)\end{array}$ & $\begin{array}{c}1.86 \\
(0.117)\end{array}$ & $\begin{array}{c}(.005) \\
0.25 \\
(0.908)\end{array}$ \\
\hline Positive Content $t_{t-1}$ & $\begin{array}{c}0.045 \\
(0.064)\end{array}$ & $\begin{array}{l}-0.004 \\
(0.024)\end{array}$ & $\begin{array}{l}-1.575 \\
(1.238)\end{array}$ & $\begin{array}{l}0.091 * \\
(0.051)\end{array}$ & $\begin{array}{c}0.041 \\
(0.029)\end{array}$ & $\begin{array}{c}0.012 \\
(0.009)\end{array}$ & $\begin{array}{l}-0.070 \\
(0.173)\end{array}$ & $\begin{array}{c}0.112 \\
(0.069)\end{array}$ & $\begin{array}{c}0.043 \\
(0.041)\end{array}$ & $\begin{array}{c}0.002 \\
(0.014)\end{array}$ & $\begin{array}{c}0.277 \\
(0.401)\end{array}$ & $\begin{array}{c}0.073 \\
(0.052)\end{array}$ \\
\hline Positive Content $t_{-2}$ & $\begin{array}{l}-0.051 \\
(0.068)\end{array}$ & $\begin{array}{l}-0.047 * * \\
(0.019)\end{array}$ & $\begin{array}{c}0.263 \\
(0.975)\end{array}$ & $\begin{array}{l}0.131 * * * * \\
(0.044)\end{array}$ & $\begin{array}{l}-0.041 \\
(0.028)\end{array}$ & $\begin{array}{c}0.007 \\
(0.009)\end{array}$ & $\begin{array}{l}-0.088 \\
(0.179)\end{array}$ & $\begin{array}{c}0.208 * * * \\
(0.054)\end{array}$ & $\begin{array}{l}-0.006 \\
(0.043)\end{array}$ & $\begin{array}{c}0.006 \\
(0.012)\end{array}$ & $\begin{array}{l}-0.559^{*} \\
(0.303)\end{array}$ & $\begin{array}{c}0.051 \\
(0.054)\end{array}$ \\
\hline Positive Content $t_{-3}$ & $\begin{array}{c}0.031 \\
(0.057)\end{array}$ & $\begin{array}{c}0.015 \\
(0.021)\end{array}$ & $\begin{array}{c}1.663 \\
(1.206)\end{array}$ & $\begin{array}{l}0.184 * * * * \\
(0.047)\end{array}$ & $\begin{array}{l}-0.036 \\
(0.028)\end{array}$ & $\begin{array}{l}-0.016^{*} \\
(0.010)\end{array}$ & $\begin{array}{c}0.336 \\
(0.217)\end{array}$ & $\begin{array}{c}0.014 \\
(0.069)\end{array}$ & $\begin{array}{l}-0.003 \\
(0.040)\end{array}$ & $\begin{array}{l}-0.003 \\
(0.012)\end{array}$ & $\begin{array}{l}-0.185 \\
(0.371)\end{array}$ & $\begin{array}{c}0.081 \\
(0.059)\end{array}$ \\
\hline Positive Content $t_{-4}$ & $\begin{array}{c}0.056 \\
(0.071)\end{array}$ & $\begin{array}{c}0.025 \\
(0.018)\end{array}$ & $\begin{array}{l}-2.519 * * \\
(1.004)\end{array}$ & $\begin{array}{c}0.046 \\
(0.047)\end{array}$ & $\begin{array}{c}0.020 \\
(0.028)\end{array}$ & $\begin{array}{l}-0.004 \\
(0.008)\end{array}$ & $\begin{array}{c}0.098 \\
(0.224)\end{array}$ & $\begin{array}{c}0.092 \\
(0.072)\end{array}$ & $\begin{array}{l}0.081^{*} \\
(0.046)\end{array}$ & $\begin{array}{c}0.020 \\
(0.014)\end{array}$ & $\begin{array}{l}-0.131 \\
(0.365)\end{array}$ & $\begin{array}{l}-0.014 \\
(0.051)\end{array}$ \\
\hline$\chi^{2}$ & $\begin{array}{c}0.74 \\
(0.565)\end{array}$ & $\begin{array}{l}2.37^{*} \\
(0.052)\end{array}$ & $\begin{array}{l}2.78 * * \\
(0.027)\end{array}$ & $\begin{array}{c}10.82 * * * * \\
(0.000)\end{array}$ & $\begin{array}{l}2.08^{*} \\
(0.083)\end{array}$ & $\begin{array}{l}1.19 \\
(0314)\end{array}$ & $\begin{array}{l}0.73 \\
(0.575)\end{array}$ & $\begin{array}{l}5.61 * * * \\
(0.000)\end{array}$ & $\begin{array}{l}1.02 \\
(0.397)\end{array}$ & $\begin{array}{c}0.93 \\
(0.446)\end{array}$ & $\begin{array}{l}1.03 \\
(0.391)\end{array}$ & $\begin{array}{l}1.83 \\
(0.122)\end{array}$ \\
\hline $\begin{array}{l}\text { P-vanstant } \\
\text { Constan }\end{array}$ & $\begin{array}{l}(0.50) \\
-0.016 \\
(0.012)\end{array}$ & $\begin{array}{c}0.002) \\
0.001 \\
(0.004)\end{array}$ & $\begin{array}{c}0.629^{* * * *} \\
(0.196)\end{array}$ & $\begin{array}{c}0.064 * * * * \\
(0.009)\end{array}$ & $\begin{array}{c}0.003 \\
(0.006)\end{array}$ & $\begin{array}{c}0.001 \\
(0.002)\end{array}$ & $\begin{array}{l}-0.014 \\
(0.042)\end{array}$ & $\begin{array}{c}0.086 \text { ) } \\
(0.019) \\
\end{array}$ & $\begin{array}{l}-0.021^{*} \\
(0.011)\end{array}$ & $\begin{array}{l}-0.003 \\
(0.002)\end{array}$ & $\begin{array}{c}0.376^{* * * *} \\
(0.068)\end{array}$ & $\begin{array}{c}0.088^{* * * *} \\
(0.011)\end{array}$ \\
\hline Obs. & 413 & 413 & 413 & 413 & 308 & 308 & 308 & 308 & 379 & 379 & 379 & 379 \\
\hline
\end{tabular}


Table 5. Newey-West Regressions of Subjective Assessments of Media Coverage and Stock Market Performance, Oct 1843 to Oct 1847

\begin{tabular}{|c|c|c|c|c|c|c|c|c|c|c|c|c|}
\hline & \multicolumn{4}{|c|}{ Railway Times } & \multicolumn{4}{|c|}{ Economist Railway Monitor } & \multicolumn{4}{|c|}{ Economist Front Page } \\
\hline & $\begin{array}{c}\text { Railway } \\
\text { Return } \\
(1) \\
\end{array}$ & $\begin{array}{c}\text { Non-Rail } \\
\text { Return } \\
(2) \\
\end{array}$ & $\begin{array}{c}\text { Reporting } \\
\text { (3) } \\
\end{array}$ & $\begin{array}{c}\text { Forecast } \\
(4) \\
\end{array}$ & $\begin{array}{c}\text { Railway } \\
\text { Return } \\
\text { (5) }\end{array}$ & $\begin{array}{c}\text { Non-Rail } \\
\text { Return } \\
(6) \\
\end{array}$ & $\begin{array}{c}\text { Reporting } \\
\text { (7) } \\
\end{array}$ & $\begin{array}{c}\text { Forecast } \\
(8) \\
\end{array}$ & $\begin{array}{c}\text { Railway } \\
\text { Return } \\
(9) \\
\end{array}$ & $\begin{array}{c}\text { Non-Rail } \\
\text { Return } \\
(10) \\
\end{array}$ & $\begin{array}{c}\text { Reporting } \\
\text { (11) } \\
\end{array}$ & $\begin{array}{c}\text { Forecast } \\
(12) \\
\end{array}$ \\
\hline Railway Return $t-1$ & $\begin{array}{c}0.086 \\
(0.079)\end{array}$ & $\begin{array}{l}0.039^{*} \\
(0.021)\end{array}$ & $\begin{array}{l}-0.151 \\
(0.850)\end{array}$ & $\begin{array}{c}0.961 \\
(0.740)\end{array}$ & $\begin{array}{c}0.019 \\
(0.097)\end{array}$ & $\begin{array}{c}0.021 \\
(0.022)\end{array}$ & $\begin{array}{l}-1.441 \\
(1.382)\end{array}$ & $\begin{array}{c}0.162 \\
(0.393)\end{array}$ & $\begin{array}{c}0.044 \\
(0.080)\end{array}$ & $\begin{array}{c}0.040 * * \\
(0.018)\end{array}$ & $\begin{array}{l}-1.469 \\
(1.605)\end{array}$ & $\begin{array}{l}-0.883 \\
(0.751)\end{array}$ \\
\hline Railway Return $\mathrm{t}_{-2}$ & $\begin{array}{c}0.066 \\
(0.080)\end{array}$ & $\begin{array}{c}0.001 \\
(0.020)\end{array}$ & $\begin{array}{l}1.724 * * \\
(0.785)\end{array}$ & $\begin{array}{l}-0.023 \\
(0.729)\end{array}$ & $\begin{array}{c}0.106 \\
(0.100)\end{array}$ & $\begin{array}{c}0.014 \\
(0.026)\end{array}$ & $\begin{array}{l}1.026 \\
(0.683)\end{array}$ & $\begin{array}{c}0.241 \\
(0.445)\end{array}$ & $\begin{array}{c}0.049 \\
(0.078)\end{array}$ & $\begin{array}{l}-0.005 \\
(0.018)\end{array}$ & $\begin{array}{c}0.637 \\
(1.614)\end{array}$ & $\begin{array}{l}-0.652 \\
(0.586)\end{array}$ \\
\hline Railway Return $\mathrm{t}_{\mathrm{t}-3}$ & $\begin{array}{c}0.127 \\
(0.093)\end{array}$ & $\begin{array}{c}0.017 \\
(0.024)\end{array}$ & $\begin{array}{l}-0.321 \\
(0.887)\end{array}$ & $\begin{array}{c}0.043 \\
(0.566)\end{array}$ & $\begin{array}{c}0.115 \\
(0.106)\end{array}$ & $\begin{array}{l}-0.007 \\
(0.023)\end{array}$ & $\begin{array}{l}-0.524 \\
(0.857)\end{array}$ & $\begin{array}{c}0.199 \\
(0.357)\end{array}$ & $\begin{array}{c}0.086 \\
(0.092)\end{array}$ & $\begin{array}{c}0.006 \\
(0.022)\end{array}$ & $\begin{array}{c}1.585 \\
(1.400)\end{array}$ & $\begin{array}{c}0.646 \\
(1.196)\end{array}$ \\
\hline Railway Return $\mathrm{t}_{\mathrm{t}-4}$ & $\begin{array}{c}0.034 \\
(0.106)\end{array}$ & $\begin{array}{c}0.012 \\
(0.034)\end{array}$ & $\begin{array}{c}0.432 \\
(0.964)\end{array}$ & $\begin{array}{l}1.554 * \\
(0.871)\end{array}$ & $\begin{array}{c}0.063 \\
(0.123)\end{array}$ & $\begin{array}{r}0.023 \\
(0.040)\end{array}$ & $\begin{array}{c}0.964 \\
(0.946)\end{array}$ & $\begin{array}{c}0.167 \\
(0.469)\end{array}$ & $\begin{array}{c}0.021 \\
(0.104)\end{array}$ & $\begin{array}{c}0.018 \\
(0.030)\end{array}$ & $\begin{array}{l}3.945 * * \\
(1.533)\end{array}$ & $\begin{array}{l}-0.527 \\
(0.840)\end{array}$ \\
\hline $\begin{array}{l}\chi^{2} \\
p \text {-value }\end{array}$ & $\begin{array}{c}1.74 \\
(0.143)\end{array}$ & $\begin{array}{c}1.12 \\
(0.348)\end{array}$ & $\begin{array}{c}1.45 \\
(0.220)\end{array}$ & $\begin{array}{c}1.84 \\
(0.123)\end{array}$ & $\begin{array}{c}1.19 \\
(0.319)\end{array}$ & $\begin{array}{c}0.77 \\
(0.548) \\
\end{array}$ & $\begin{array}{c}1.12 \\
(0.348)\end{array}$ & $\begin{array}{c}0.61 \\
(0.658)\end{array}$ & $\begin{array}{c}0.86 \\
(0.490)\end{array}$ & $\begin{array}{l}1.26 \\
(0.289)\end{array}$ & $\begin{array}{c}1.82 \\
(0.127)\end{array}$ & $\begin{array}{c}0.68 \\
(0.604)\end{array}$ \\
\hline Non-Railway Return ${ }_{t-1}$ & $\begin{array}{c}0.285 \\
(0.284)\end{array}$ & $\begin{array}{c}0.097 \\
(0.115)\end{array}$ & $\begin{array}{c}2.986 \\
(4.217)\end{array}$ & $\begin{array}{l}-1.901 \\
(1.855)\end{array}$ & $\begin{array}{c}0.354 \\
(0.396)\end{array}$ & $\begin{array}{l}0.216^{*} \\
(0.128)\end{array}$ & $\begin{array}{c}3.323 \\
(3.265)\end{array}$ & $\begin{array}{c}0.418 \\
(0.746)\end{array}$ & $\begin{array}{c}0.116 \\
(0.238)\end{array}$ & $\begin{array}{c}0.082 \\
(0.089)\end{array}$ & $\begin{array}{l}10.237^{*} \\
(5.288)\end{array}$ & $\begin{array}{c}1.396 \\
(4.110)\end{array}$ \\
\hline Non-Railway Return ${ }_{t-2}$ & $\begin{array}{l}-0.015 \\
(0.304)\end{array}$ & $\begin{array}{l}-0.014 \\
(0.111)\end{array}$ & $\begin{array}{c}1.813 \\
(5.066)\end{array}$ & $\begin{array}{l}-1.951 \\
(3.310)\end{array}$ & $\begin{array}{l}-0.282 \\
(0.432)\end{array}$ & $\begin{array}{l}-0.215 \\
(0.166)\end{array}$ & $\begin{array}{l}-1.584 \\
(3.688)\end{array}$ & $\begin{array}{l}-1.232 \\
(1.694)\end{array}$ & $\begin{array}{l}-0.128 \\
(0.315)\end{array}$ & $\begin{array}{l}-0.047 \\
(0.124)\end{array}$ & $\begin{array}{l}-12.427 \\
(9.281)\end{array}$ & $\begin{array}{c}1.361 \\
(4.465)\end{array}$ \\
\hline Non-Railway Return ${ }_{t-3}$ & $\begin{array}{l}-0.052 \\
(0.320)\end{array}$ & $\begin{array}{c}0.046 \\
(0.098)\end{array}$ & $\begin{array}{l}7.000) \\
(3.454)\end{array}$ & $\begin{array}{l}-2.584 \\
(2.840)\end{array}$ & $\begin{array}{l}-0.042 \\
(0.553)\end{array}$ & $\begin{array}{c}(0.100) \\
0.146 \\
(0.146)\end{array}$ & $\begin{array}{l}-0.567) \\
(3.089)\end{array}$ & $\begin{array}{c}0.424 \\
(1.100)\end{array}$ & $\begin{array}{l}-0.112 \\
(0.279)\end{array}$ & $\begin{array}{c}(0.124) \\
0.033 \\
(0.101)\end{array}$ & $\begin{array}{l}-1.354 \\
(7.209)\end{array}$ & $\begin{array}{l}(4.405) \\
-1.089 \\
(3.122)\end{array}$ \\
\hline Non-Railway Return ${ }_{t-4}$ & $\begin{array}{l}-0.397 \\
(0.265)\end{array}$ & $\begin{array}{c}0.233^{* * *} \\
(0.091)\end{array}$ & $\begin{array}{l}-2.351 \\
(3.820)\end{array}$ & $\begin{array}{l}-1.624 \\
(2.229)\end{array}$ & $\begin{array}{l}-0.832^{* * *} \\
(0.386)\end{array}$ & $\begin{array}{l}-0.023 \\
(0.118)\end{array}$ & $\begin{array}{c}2.616 \\
(4.243)\end{array}$ & $\begin{array}{c}1.542 \\
(1.175)\end{array}$ & $\begin{array}{l}-0.320 \\
(0.303)\end{array}$ & $\begin{array}{c}0.212 * * * * \\
(0.076)\end{array}$ & $\begin{array}{c}10.607 * * \\
(5.006)\end{array}$ & $\begin{array}{c}6.237 \\
(4.231)\end{array}$ \\
\hline $\begin{array}{l}\chi^{2} \\
\text { p-value }\end{array}$ & $\begin{array}{c}1.52 \\
(0.198) \\
\end{array}$ & $\begin{array}{l}4.16 * * * \\
(0.003) \\
\end{array}$ & $\begin{array}{c}2.16^{*} \\
(0.075) \\
\end{array}$ & $\begin{array}{c}1.02 \\
(0.399) \\
\end{array}$ & $\begin{array}{c}1.76 \\
(0.141) \\
\end{array}$ & $\begin{array}{c}1.45 \\
(0.223) \\
\end{array}$ & $\begin{array}{c}0.38 \\
(0.822) \\
\end{array}$ & $\begin{array}{c}0.65 \\
(0.629) \\
\end{array}$ & $\begin{array}{c}0.45 \\
(0.774) \\
\end{array}$ & $\begin{array}{l}3.61^{* * * *} \\
(0.007) \\
\end{array}$ & $\begin{array}{c}2.06^{*} \\
(0.088) \\
\end{array}$ & $\begin{array}{c}0.62 \\
(0.647) \\
\end{array}$ \\
\hline Reporting $\mathrm{t}_{-1}$ & $\begin{array}{c}0.001 \\
(0.004)\end{array}$ & $\begin{array}{l}-0.003^{*} \\
(0.002)\end{array}$ & $\begin{array}{c}0.076 \\
(0.064)\end{array}$ & $\begin{array}{c}0.016 \\
(0.045)\end{array}$ & $\begin{array}{c}0.007 \\
(0.009)\end{array}$ & $\begin{array}{c}0.000 \\
(0.002)\end{array}$ & $\begin{array}{c}0.121 \\
(0.091)\end{array}$ & $\begin{array}{l}-0.006 \\
(0.020)\end{array}$ & $\begin{array}{c}0.004 \\
(0.004)\end{array}$ & $\begin{array}{c}0.001 \\
(0.001)\end{array}$ & $\begin{array}{c}0.112 \\
(0.097)\end{array}$ & $\begin{array}{c}0.009 \\
(0.047)\end{array}$ \\
\hline Reporting $_{t-2}$ & $\begin{array}{l}0.012^{* *} \\
(0.005)\end{array}$ & $\begin{array}{l}-0.000 \\
(0.001)\end{array}$ & $\begin{array}{c}0.094 \\
(0.071)\end{array}$ & $\begin{array}{c}0.063 \\
(0.048)\end{array}$ & $\begin{array}{l}-0.003 \\
(0.007)\end{array}$ & $\begin{array}{l}-0.001 \\
(0.002)\end{array}$ & $\begin{array}{c}0.098 \\
(0.069)\end{array}$ & $\begin{array}{c}0.010 \\
(0.015)\end{array}$ & $\begin{array}{c}0.008 * * \\
(0.003)\end{array}$ & $\begin{array}{l}0.001 * \\
(0.001)\end{array}$ & $\begin{array}{c}0.213 * * \\
(0.089)\end{array}$ & $\begin{array}{c}0.100 \\
(0.063)\end{array}$ \\
\hline Reporting $_{\mathrm{t}-3}$ & $\begin{array}{c}0.000 \\
(0.005)\end{array}$ & $\begin{array}{c}0.000 \\
(0.002)\end{array}$ & $\begin{array}{l}-0.047 \\
(0.095)\end{array}$ & $\begin{array}{l}-0.050 \\
(0.047)\end{array}$ & $\begin{array}{l}-0.005 \\
(0.008)\end{array}$ & $\begin{array}{c}0.000 \\
(0.002)\end{array}$ & $\begin{array}{l}-0.049 \\
(0.075)\end{array}$ & $\begin{array}{l}-0.022 \\
(0.032)\end{array}$ & $\begin{array}{c}0.000 \\
(0.003)\end{array}$ & $\begin{array}{l}-0.001 \\
(0.001)\end{array}$ & $\begin{array}{c}0.040 \\
(0.075)\end{array}$ & $\begin{array}{l}-0.042 \\
(0.075)\end{array}$ \\
\hline Reporting $_{t-4}$ & $\begin{array}{c}0.004 \\
(0.004)\end{array}$ & $\begin{array}{l}-0.001 \\
(0.001)\end{array}$ & $\begin{array}{l}-0.034 \\
(0.092)\end{array}$ & $\begin{array}{c}0.042 \\
(0.053)\end{array}$ & $\begin{array}{l}-0.001 \\
(0.008)\end{array}$ & $\begin{array}{l}-0.001 \\
(0.002)\end{array}$ & $\begin{array}{l}-0.030 \\
(0.090)\end{array}$ & $\begin{array}{c}0.049 \\
(0.050)\end{array}$ & $\begin{array}{l}-0.001 \\
(0.005)\end{array}$ & $\begin{array}{l}-0.000 \\
(0.002)\end{array}$ & $\begin{array}{l}-0.099 \\
(0.114)\end{array}$ & $\begin{array}{l}-0.091 \\
(0.076)\end{array}$ \\
\hline $\begin{array}{l}\chi^{2} \\
\text { p-value }\end{array}$ & $\begin{array}{c}2.02 * \\
(0.093)\end{array}$ & $\begin{array}{c}1.18 \\
(0.322)\end{array}$ & $\begin{array}{c}1.09 \\
(0.363)\end{array}$ & $\begin{array}{c}0.91 \\
(0.458)\end{array}$ & $\begin{array}{c}0.25 \\
(0.910)\end{array}$ & $\begin{array}{c}0.13 \\
(0.970)\end{array}$ & $\begin{array}{c}0.96 \\
(0.432)\end{array}$ & $\begin{array}{c}0.37 \\
(0.832)\end{array}$ & $\begin{array}{l}1.75 \\
(0.141)\end{array}$ & $\begin{array}{c}0.99 \\
(0.415)\end{array}$ & $\begin{array}{l}2.67^{* *} \\
(0.034)\end{array}$ & $\begin{array}{c}0.69 \\
(0.601)\end{array}$ \\
\hline Forecasting $\mathrm{t}_{\mathrm{t}-1}$ & $\begin{array}{l}-0.010 \\
(0.006)\end{array}$ & $\begin{array}{c}0.000 \\
(0.002)\end{array}$ & $\begin{array}{c}0.150 \\
(0.095)\end{array}$ & $\begin{array}{c}0.155^{* * *} \\
(0.074)\end{array}$ & $\begin{array}{c}0.036 \\
(0.038)\end{array}$ & $\begin{array}{c}0.008 \\
(0.007)\end{array}$ & $\begin{array}{c}0.663^{* * *} \\
(0.323)\end{array}$ & $\begin{array}{l}-0.001 \\
(0.093)\end{array}$ & $\begin{array}{c}0.001 \\
(0.005)\end{array}$ & $\begin{array}{c}0.000 \\
(0.002)\end{array}$ & $\begin{array}{l}-0.102 \\
(0.202)\end{array}$ & $\begin{array}{l}0.224^{*} \\
(0.126)\end{array}$ \\
\hline Forecasting $_{\mathrm{t}-2}$ & $\begin{array}{l}-0.001 \\
(0.007)\end{array}$ & $\begin{array}{l}-0.001 \\
(0.002)\end{array}$ & $\begin{array}{c}0.009 \\
(0.102)\end{array}$ & $\begin{array}{c}0.038 \\
(0.055)\end{array}$ & $\begin{array}{c}0.003 \\
(0.028)\end{array}$ & $\begin{array}{l}-0.003 \\
(0.004)\end{array}$ & $\begin{array}{l}-0.014 \\
(0.153)\end{array}$ & $\begin{array}{l}-0.147 \\
(0.118)\end{array}$ & $\begin{array}{l}-0.005 \\
(0.006)\end{array}$ & $\begin{array}{l}-0.001 \\
(0.001)\end{array}$ & $\begin{array}{l}-0.032 \\
(0.078)\end{array}$ & $\begin{array}{c}0.045 \\
(0.046)\end{array}$ \\
\hline Forecasting $_{\mathrm{t}-3}$ & $\begin{array}{l}-0.012 \\
(0.009)\end{array}$ & $\begin{array}{c}0.001 \\
(0.002)\end{array}$ & $\begin{array}{l}-0.039 \\
(0.086)\end{array}$ & $\begin{array}{c}0.038 \\
(0.060)\end{array}$ & $\begin{array}{c}0.017 \\
(0.015)\end{array}$ & $\begin{array}{l}-0.001 \\
(0.004)\end{array}$ & $\begin{array}{l}-0.366 \\
(0.230)\end{array}$ & $\begin{array}{c}0.035 \\
(0.067)\end{array}$ & $\begin{array}{l}0.014 * \\
(0.007)\end{array}$ & $\begin{array}{l}0.004 * * \\
(0.002)\end{array}$ & $\begin{array}{c}0.083 \\
(0.156)\end{array}$ & $\begin{array}{c}0.151 \\
(0.108)\end{array}$ \\
\hline Forecasting $_{t-4}$ & $\begin{array}{c}0.003 \\
(0.007)\end{array}$ & $\begin{array}{c}0.000 \\
(0.002)\end{array}$ & $\begin{array}{c}0.132 \\
(0.096)\end{array}$ & $\begin{array}{c}0.107 \\
(0.083)\end{array}$ & $\begin{array}{c}0.019 \\
(0.018)\end{array}$ & $\begin{array}{c}0.002 \\
(0.003)\end{array}$ & $\begin{array}{c}0.138 \\
(0.180)\end{array}$ & $\begin{array}{l}-0.056 \\
(0.048)\end{array}$ & $\begin{array}{c}0.008 \\
(0.006)\end{array}$ & $\begin{array}{l}-0.003 \\
(0.003)\end{array}$ & $\begin{array}{l}-0.041 \\
(0.097)\end{array}$ & $\begin{array}{c}0.075 \\
(0.068)\end{array}$ \\
\hline $\begin{array}{l}\chi^{2} \\
\text { p-value }\end{array}$ & $\begin{array}{c}1.80 \\
(0.130)\end{array}$ & $\begin{array}{c}0.14 \\
(0.969)\end{array}$ & $\begin{array}{c}1.26 \\
(0.288)\end{array}$ & $\begin{array}{l}2.67 * * \\
(0.034)\end{array}$ & $\begin{array}{c}0.87 \\
(0.486)\end{array}$ & $\begin{array}{c}0.38 \\
(0.824)\end{array}$ & $\begin{array}{l}7.05^{* * * *} \\
(0.000)\end{array}$ & $\begin{array}{c}0.86 \\
(0.490)\end{array}$ & $\begin{array}{c}1.89 \\
(0.114)\end{array}$ & $\begin{array}{c}1.32 \\
(0.265)\end{array}$ & $\begin{array}{c}0.62 \\
(0.647)\end{array}$ & $\begin{array}{c}1.30 \\
(0.271)\end{array}$ \\
\hline Constant & $\begin{array}{l}0.003^{*} \\
(0.002)\end{array}$ & $\begin{array}{l}-0.001 \\
(0.000)\end{array}$ & $\begin{array}{c}-0.100 * * * * \\
(0.024)\end{array}$ & $\begin{array}{l}0.032^{*} \\
(0.018)\end{array}$ & $\begin{array}{c}-0.002 \\
(0.002)\end{array}$ & $\begin{array}{c}-0.001 * * \\
(0.000)\end{array}$ & $\begin{array}{c}-0.002 \\
(0.018)\end{array}$ & $\begin{array}{c}0.000 \\
(0.005)\end{array}$ & $\begin{array}{c}0.002 \\
(0.001)\end{array}$ & $\begin{array}{c}-0.000 \\
(0.000)\end{array}$ & $\begin{array}{c}-0.061 * * * \\
(0.028)\end{array}$ & $\begin{array}{c}-0.025 \\
(0.016)\end{array}$ \\
\hline Obs. & 209 & 209 & 209 & 209 & 143 & 143 & 143 & 143 & 209 & 209 & 209 & 209 \\
\hline
\end{tabular}

Notes: Where Railway Return $\mathrm{t}_{\mathrm{tn}}$ denotes the weekly return of a value-weighted index of railway stocks, Non-Railway Return $\mathrm{t}_{\mathrm{tn}}$ denotes the weekly return of a value-weighted index of a sample of non-railway stocks, Reporting $\mathrm{g}_{\mathrm{t} \mathrm{n}}$ denotes a subjective assessment of the positivity of the reporting of recent events, and Forecasting $t_{t-n}$ denotes a subjective assessment of the positivity of the forecasts made, in the respective newspapers. ${ }^{2}$ values represent Granger-causality results testing the joint examined for the sample period beginning in October 1843, and ending in October 1847. 
Table 6. Event Studies for The Times and Economist Editorials

\begin{tabular}{|c|c|c|c|c|c|c|}
\hline \multicolumn{7}{|c|}{ Abnormal Return = Railways' Return Minus: } \\
\hline & & Zero & $\begin{array}{c}\text { Non- } \\
\text { Railway } \\
\text { Return }\end{array}$ & Risk-free & $\begin{array}{l}\text { Beta* } \\
\text { Non- } \\
\text { Railway } \\
\text { Return }\end{array}$ & $\begin{array}{c}\text { Beta* } \\
\text { Non- } \\
\text { Railway } \\
\text { Return } \\
\text { with lags }\end{array}$ \\
\hline \multicolumn{7}{|c|}{ The Times } \\
\hline \multirow[t]{3}{*}{$\mathrm{N}=39$} & Mean & $0.38 \%$ & $0.39 \%$ & $0.31 \%$ & $0.51 \%$ & $0.47 \%$ \\
\hline & SE & $0.26 \%$ & $0.26 \%$ & $0.26 \%$ & $0.26 \%$ & $0.24 \%$ \\
\hline & t-test & 1.45 & 1.50 & 1.21 & 1.96 & 1.93 \\
\hline \multicolumn{7}{|c|}{ Economist } \\
\hline \multirow[t]{3}{*}{$\mathrm{N}=16$} & Mean & $0.38 \%$ & $0.54 \%$ & $0.32 \%$ & $0.69 \%$ & $0.81 \%$ \\
\hline & SE & $0.22 \%$ & $0.19 \%$ & $0.22 \%$ & $0.19 \%$ & $0.23 \%$ \\
\hline & $\mathrm{t}$-test & 1.74 & 2.86 & 1.45 & 3.68 & 3.51 \\
\hline
\end{tabular}

Notes: Event window of one week. The Times published 41 editorials concerning the railways, but in some cases these were during the same week, so there are 39 weeks of events. Railway return calculated as the percentage change in a railway market index consisting of all railway stocks weighted by market capitalisation. Non-railway return calculated based on an index of the twenty-two largest non-railway stocks by market capitalisation. Risk-free rate calculated from the yield on Consols, which were government debt perpetuities. Beta is calculated by regressing the railway return minus the risk-free rate, against the non-railway return minus risk-free rate for the full sample period. The beta with lags also includes lags of the non-railway return in the estimation of beta, in line with the Dimson (1979) thin-trading correction. 
Table 7. Extent of Coverage of the Cross-Section of Stocks

\begin{tabular}{|c|c|c|c|c|c|c|}
\hline & \multicolumn{2}{|c|}{$\begin{array}{c}\% \text { of stocks covered at least } \\
\text { once per year }\end{array}$} & \multicolumn{4}{|c|}{$\begin{array}{l}\text { Number of Columns in which a } \\
\text { particular company was mentioned }\end{array}$} \\
\hline & $\begin{array}{l}\text { Railway } \\
\text { Times }\end{array}$ & $\begin{array}{c}\text { Economist's } \\
\text { railway } \\
\text { supplement }\end{array}$ & Mean & Median & Max & Min \\
\hline 1843 & $92.1 \%$ & $0.0 \%$ & 97.5 & 42.0 & 528.0 & 1.0 \\
\hline 1844 & $87.6 \%$ & $0.0 \%$ & 61.4 & 23.5 & 585.0 & 1.0 \\
\hline 1845 & $88.2 \%$ & $52.5 \%$ & 58.2 & 12.0 & 1307.0 & 1.0 \\
\hline 1846 & $81.0 \%$ & $72.2 \%$ & 62.9 & 29.5 & 916.0 & 1.0 \\
\hline 1847 & $86.8 \%$ & $73.0 \%$ & 68.8 & 40.0 & 704.0 & 1.0 \\
\hline 1848 & $90.9 \%$ & $73.6 \%$ & 70.2 & 37.0 & 610.0 & 1.0 \\
\hline 1849 & $92.9 \%$ & $51.0 \%$ & 61.2 & 29.5 & 507.0 & 1.0 \\
\hline 1850 & $87.7 \%$ & $52.8 \%$ & 65.0 & 24.0 & 573.0 & 1.0 \\
\hline $1843-50$ & $85.1 \%$ & $68.3 \%$ & 205.2 & 42.0 & 4810.0 & 1.0 \\
\hline
\end{tabular}


Table 8. Fama-MacBeth Regressions Explaining the Extent of Media Coverage of Each Company Per Year

\begin{tabular}{lcc}
\hline \hline & $(1)$ & $(2)$ \\
\hline \multirow{2}{*}{ Size } & $62.389^{* * *}$ & $62.752 * * *$ \\
& $(8.884)$ & $(9.060)$ \\
Par/Price & -4.638 & -6.851 \\
& $(4.281)$ & $(3.876)$ \\
Annual Return & -7.096 & \\
Absolute Annual Return & $(13.932)$ & $40.006^{* *}$ \\
Constant & & $(12.749)$ \\
& $35.742 * * *$ & $32.526^{* * *}$ \\
Observations & $(5.940)$ & $(4.798)$ \\
R-squared & 798 & 798 \\
Number of time periods & 0.506 & 0.505 \\
& 7 & 7
\end{tabular}

Notes: Dependent variable is the total number of columns in which a company is mentioned in a given year. Size is market capitalisation in £m, Par/Price is the par value of a share as a fraction of its market price, Annual Return is the annual return from the previous year, Absolute Annual Return is simply the absolute value of the annual return. Standard errors in parentheses. $* * * \mathrm{p}<0.01, * * \mathrm{p}<0.05, * \mathrm{p}<0.1$ 
Table 9. Media Coverage and Stock Returns: Univariate Comparisons

\begin{tabular}{|c|c|c|c|c|c|c|c|c|c|c|c|c|c|c|c|c|}
\hline \multirow[b]{3}{*}{ Overall } & & \multicolumn{5}{|c|}{ All periods } & \multicolumn{5}{|c|}{ Boom } & \multicolumn{5}{|c|}{ Bust } \\
\hline & & No & Low & Extensive & $\begin{array}{c}\text { No- } \\
\text { Extensive }\end{array}$ & $\begin{array}{c}\text { t-stat for } \\
\text { No- } \\
\text { Extensive } \\
\end{array}$ & No & Low & Extensive & $\begin{array}{c}\text { No- } \\
\text { Extensive }\end{array}$ & $\begin{array}{c}\text { t-stat for } \\
\text { No- } \\
\text { Extensive } \\
\end{array}$ & No & Low & Extensive & $\begin{array}{c}\text { No- } \\
\text { Extensive }\end{array}$ & $\begin{array}{c}\text { t-stat for } \\
\text { No- } \\
\text { Extensive } \\
\end{array}$ \\
\hline & & $-5.6 \%$ & $-3.0 \%$ & $-2.5 \%$ & $-3.1 \%$ & -2.67 & $0.1 \%$ & $4.5 \%$ & $3.2 \%$ & $-3.1 \%$ & -1.83 & $-7.2 \%$ & $-5.7 \%$ & $-4.6 \%$ & $-2.6 \%$ & -1.87 \\
\hline \multirow[t]{3}{*}{ Size } & 0 & $-8.5 \%$ & $-3.8 \%$ & $-4.8 \%$ & $-3.8 \%$ & -1.01 & $-1.8 \%$ & $6.1 \%$ & $10.4 \%$ & $-12.2 \%$ & -2.68 & $-10.4 \%$ & $-7.4 \%$ & $-9.6 \%$ & $-0.8 \%$ & -0.18 \\
\hline & 1 & $-2.4 \%$ & $-3.5 \%$ & $-4.2 \%$ & $1.8 \%$ & 1.12 & $3.9 \%$ & $5.3 \%$ & $2.3 \%$ & $1.7 \%$ & 0.57 & $-4.1 \%$ & $-6.3 \%$ & $-6.9 \%$ & $2.7 \%$ & 1.43 \\
\hline & 2 & $-0.9 \%$ & $-1.1 \%$ & $-1.2 \%$ & $0.3 \%$ & 0.23 & $-1.5 \%$ & $1.0 \%$ & $2.3 \%$ & $-3.8 \%$ & -1.30 & $-0.7 \%$ & $-1.9 \%$ & $-2.4 \%$ & $1.8 \%$ & 1.10 \\
\hline \multirow[t]{3}{*}{ Par/Price } & 0 & $-8.5 \%$ & $-4.4 \%$ & $-3.6 \%$ & $-4.9 \%$ & -2.78 & $-4.2 \%$ & $3.3 \%$ & $0.3 \%$ & $-4.5 \%$ & -1.56 & $-9.9 \%$ & $-7.2 \%$ & $-5.0 \%$ & $-4.8 \%$ & -2.27 \\
\hline & 1 & $-7.5 \%$ & $-4.1 \%$ & $-2.2 \%$ & $-5.3 \%$ & -3.45 & $0.2 \%$ & $1.7 \%$ & $2.1 \%$ & $-2.0 \%$ & -0.91 & $-9.7 \%$ & $-6.1 \%$ & $-3.8 \%$ & $-5.9 \%$ & -3.07 \\
\hline & 2 & $-2.3 \%$ & $-1.3 \%$ & $-1.4 \%$ & $-1.0 \%$ & -0.37 & $3.3 \%$ & $7.9 \%$ & $8.9 \%$ & $-5.6 \%$ & -1.60 & $-3.9 \%$ & $-4.3 \%$ & $-5.0 \%$ & $1.1 \%$ & 0.35 \\
\hline \multirow[t]{3}{*}{ Past Return } & 0 & $-3.7 \%$ & $-2.5 \%$ & $-1.0 \%$ & $-2.7 \%$ & -1.36 & $4.0 \%$ & $5.3 \%$ & $3.8 \%$ & $0.2 \%$ & 0.05 & $-5.6 \%$ & $-5.0 \%$ & $-2.5 \%$ & $-3.1 \%$ & -1.31 \\
\hline & 1 & $-4.4 \%$ & $-2.0 \%$ & $-1.9 \%$ & $-2.4 \%$ & -1.38 & $-2.1 \%$ & $4.7 \%$ & $1.9 \%$ & $-4.0 \%$ & -1.32 & $-5.2 \%$ & $-4.2 \%$ & $-3.3 \%$ & $-1.9 \%$ & -0.90 \\
\hline & 2 & $-8.8 \%$ & $-4.3 \%$ & $-4.6 \%$ & $-4.3 \%$ & -1.87 & $-0.9 \%$ & $3.8 \%$ & $3.6 \%$ & $-4.5 \%$ & -1.59 & $-10.5 \%$ & $-6.8 \%$ & $-7.7 \%$ & $-2.8 \%$ & -0.98 \\
\hline \multirow[t]{3}{*}{ Current Return } & 0 & $1.8 \%$ & $-0.9 \%$ & $-1.7 \%$ & $3.5 \%$ & 1.79 & $3.1 \%$ & $6.0 \%$ & $4.8 \%$ & $-1.7 \%$ & -0.53 & $1.5 \%$ & $-3.1 \%$ & $-4.0 \%$ & $5.4 \%$ & 2.32 \\
\hline & 1 & $-6.8 \%$ & $-2.5 \%$ & $-1.4 \%$ & $-5.4 \%$ & -3.18 & $2.3 \%$ & $5.7 \%$ & $3.8 \%$ & $-1.5 \%$ & -0.56 & $-9.9 \%$ & $-5.6 \%$ & $-3.1 \%$ & $-6.8 \%$ & -3.27 \\
\hline & 2 & $-10.0 \%$ & $-5.4 \%$ & $-4.4 \%$ & $-5.6 \%$ & -2.55 & $-3.9 \%$ & $2.2 \%$ & $1.3 \%$ & $-5.2 \%$ & -1.86 & $-11.7 \%$ & $-8.0 \%$ & $-6.9 \%$ & $-4.9 \%$ & -1.75 \\
\hline \multirow[t]{3}{*}{ Price } & 0 & $-6.1 \%$ & $-1.3 \%$ & $-0.3 \%$ & $-5.8 \%$ & -1.92 & $-0.2 \%$ & $8.4 \%$ & $8.0 \%$ & $-8.2 \%$ & -1.77 & $-7.4 \%$ & $-5.0 \%$ & $-4.0 \%$ & $-3.4 \%$ & -0.93 \\
\hline & 1 & $-7.8 \%$ & $-5.9 \%$ & $-5.2 \%$ & $-2.6 \%$ & -1.14 & $-1.0 \%$ & $2.7 \%$ & $2.8 \%$ & $-3.8 \%$ & -1.33 & $-10.3 \%$ & $-8.7 \%$ & $-8.0 \%$ & $-2.3 \%$ & -0.79 \\
\hline & 2 & $0.6 \%$ & $-1.6 \%$ & $-1.4 \%$ & $2.0 \%$ & 1.80 & $3.6 \%$ & $1.0 \%$ & $1.9 \%$ & $1.7 \%$ & 1.27 & $-0.3 \%$ & $-2.5 \%$ & $-2.5 \%$ & $2.2 \%$ & 1.54 \\
\hline \multirow[t]{3}{*}{ Liquidity } & 0 & $-11.8 \%$ & $-6.4 \%$ & $-7.9 \%$ & $-3.8 \%$ & -1.09 & $0.2 \%$ & $4.8 \%$ & $4.6 \%$ & $-4.4 \%$ & -1.03 & $-14.6 \%$ & $-10.0 \%$ & $-12.8 \%$ & $-1.8 \%$ & -0.41 \\
\hline & 1 & $1.5 \%$ & $-1.7 \%$ & $-1.4 \%$ & $2.9 \%$ & 1.84 & $0.7 \%$ & $5.0 \%$ & $4.6 \%$ & $-3.9 \%$ & -1.84 & $1.8 \%$ & $-4.1 \%$ & $-3.5 \%$ & $5.3 \%$ & 2.71 \\
\hline & 2 & $-5.6 \%$ & $-0.9 \%$ & $-1.9 \%$ & $-3.7 \%$ & -2.21 & $-1.0 \%$ & $3.6 \%$ & $2.1 \%$ & $-3.1 \%$ & -0.95 & $-7.2 \%$ & $-2.5 \%$ & $-3.3 \%$ & $-4.0 \%$ & -2.05 \\
\hline
\end{tabular}

Notes: Stocks allocated to portfolios based on rankings according to each variable, with 0 referring to lowest values, and 2 referring to highest values. Monthly returns for each stock calculated as the change in the log of price, controlling for changes in capital, referred to as par value. Monthly returns calculated for each portfolio based on an equally weighted average of individual stock returns. $t$-stats test whether the difference between No-media and Extensive-media-coverage portfolios is significantly different from zero. 
Table 10. Regressions Explaining Returns on a Portfolio which is Long on No Media Coverage Stocks, and Short on Extensive Media Coverage Stocks

\begin{tabular}{|c|c|c|c|c|c|c|}
\hline & \multicolumn{2}{|c|}{$\begin{array}{c}\text { Overall } \\
\text { (Jan 1843- Dec 1850) }\end{array}$} & \multicolumn{2}{|c|}{$\begin{array}{c}\text { Boom } \\
(\text { Jan } 1843-\text { Sept 1845) }\end{array}$} & \multicolumn{2}{|c|}{$\begin{array}{c}\text { Bust } \\
\text { (Oct 1845- Dec 1850) }\end{array}$} \\
\hline & (1) & (2) & & (4) & $(5)$ & (6) \\
\hline Mkt - Rf & $\begin{array}{l}0.320 \\
(0.247)\end{array}$ & $\begin{array}{c}0.193 \\
(0.255)\end{array}$ & $\begin{array}{l}-0.662 \\
(0.602)\end{array}$ & $\begin{array}{l}-0.319 \\
(0.653)\end{array}$ & $\begin{array}{l}0.535^{*} \\
(0.308)\end{array}$ & $\begin{array}{c}0.391 \\
(0.331)\end{array}$ \\
\hline Size SMB & & $\begin{array}{c}0.433 * * * \\
(0.123)\end{array}$ & & $\begin{array}{c}0.290 \\
(0.179)\end{array}$ & & $\begin{array}{r}0.475^{* * * *} \\
(0.166)\end{array}$ \\
\hline Book/Market HML & & $\begin{array}{c}-0.238^{* *} \\
(0.118)\end{array}$ & & $\begin{array}{l}-0.240 \\
(0.252)\end{array}$ & & $\begin{array}{l}-0.270 * \\
(0.143)\end{array}$ \\
\hline Liquidity IMM & & $\begin{array}{l}-0.109 \\
(0.098)\end{array}$ & & $\begin{array}{l}-0.017 \\
(0.252)\end{array}$ & & $\begin{array}{l}-0.085 \\
(0.120)\end{array}$ \\
\hline Constant & $\begin{array}{l}-0.021 \\
(0.013)\end{array}$ & $\begin{array}{l}-0.005 \\
(0.014)\end{array}$ & $\begin{array}{l}-0.024 \\
(0.017)\end{array}$ & $\begin{array}{l}-0.019 \\
(0.019)\end{array}$ & $\begin{array}{l}-0.007 \\
(0.018)\end{array}$ & $\begin{array}{c}0.015 \\
(0.021)\end{array}$ \\
\hline $\begin{array}{l}\text { Observations } \\
\text { R-squared }\end{array}$ & $\begin{array}{c}94 \\
0.018\end{array}$ & $\begin{array}{c}94 \\
0.150\end{array}$ & $\begin{array}{c}31 \\
0.040\end{array}$ & $\begin{array}{c}31 \\
0.159\end{array}$ & $\begin{array}{c}63 \\
0.047\end{array}$ & $\begin{array}{c}63 \\
0.184\end{array}$ \\
\hline
\end{tabular}


Appendix Table 1. Media Coverage and Stock Returns: Number of Observations in Each Portfolio

\begin{tabular}{|c|c|c|c|c|c|c|c|c|c|c|}
\hline & & \multicolumn{3}{|c|}{ Overall } & \multicolumn{3}{|c|}{ Boom } & \multicolumn{3}{|c|}{ Bust } \\
\hline & & No & Low & Extensive & No & Low & Extensive & No & Low & Extensive \\
\hline Overall & & 849 & 2262 & 2120 & 188 & 581 & 562 & 661 & 1681 & 1558 \\
\hline \multirow[t]{3}{*}{ Size } & 0 & 467 & 884 & 260 & 102 & 234 & 63 & 365 & 650 & 197 \\
\hline & 1 & 291 & 833 & 620 & 63 & 204 & 181 & 228 & 629 & 439 \\
\hline & 2 & 91 & 545 & 1240 & 23 & 143 & 318 & 68 & 402 & 922 \\
\hline \multirow[t]{3}{*}{ Par/Price } & 0 & 242 & 654 & 809 & 57 & 175 & 211 & 185 & 479 & 598 \\
\hline & 1 & 246 & 720 & 756 & 54 & 187 & 207 & 192 & 533 & 549 \\
\hline & 2 & 361 & 888 & 555 & 77 & 219 & 144 & 284 & 669 & 411 \\
\hline \multirow[t]{3}{*}{ Past Return } & 0 & 258 & 690 & 617 & 50 & 167 & 146 & 208 & 523 & 471 \\
\hline & 1 & 229 & 655 & 755 & 60 & 166 & 193 & 169 & 489 & 562 \\
\hline & 2 & 323 & 824 & 700 & 55 & 200 & 195 & 268 & 624 & 505 \\
\hline \multirow[t]{3}{*}{ Current Return } & 0 & 246 & 745 & 637 & 49 & 181 & 162 & 197 & 564 & 475 \\
\hline & 1 & 266 & 688 & 767 & 66 & 188 & 188 & 200 & 500 & 579 \\
\hline & 2 & 337 & 829 & 716 & 73 & 212 & 212 & 264 & 617 & 504 \\
\hline \multirow[t]{3}{*}{ Price } & 0 & 472 & 833 & 303 & 90 & 229 & 94 & 382 & 604 & 209 \\
\hline & 1 & 253 & 813 & 715 & 67 & 202 & 184 & 186 & 611 & 531 \\
\hline & 2 & 124 & 616 & 1102 & 31 & 150 & 284 & 93 & 466 & 818 \\
\hline \multirow[t]{3}{*}{ Liquidity } & 0 & 377 & 757 & 285 & 72 & 185 & 80 & 305 & 572 & 205 \\
\hline & 1 & 326 & 875 & 628 & 77 & 223 & 167 & 249 & 652 & 461 \\
\hline & 2 & 146 & 630 & 1207 & 39 & 173 & 315 & 107 & 457 & 892 \\
\hline
\end{tabular}


Figure 1. Sentiment of Railway Times' Editorials

Panel A: Weekly Positive Content of Railway Times' Editorials using LIWC Software, 1843-50

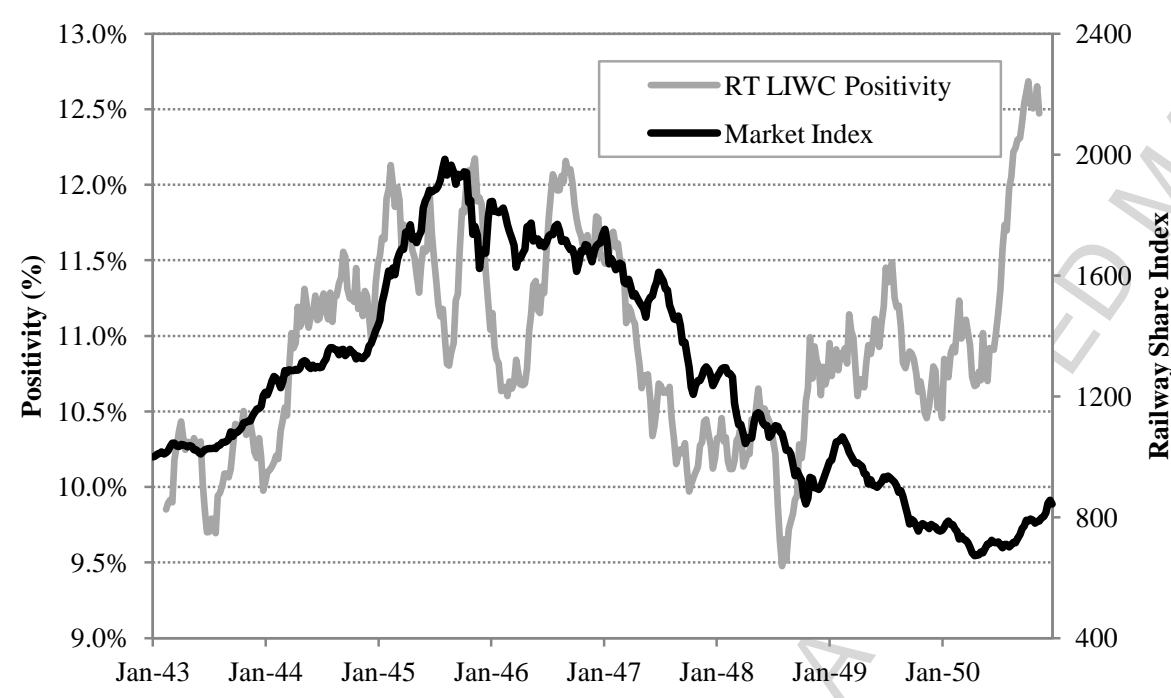

Notes: LIWC Positivity is the percentage of positive words, as defined by Linguistic Inquiry and Word Count (LIWC), in an article divided by the psychological processes word count,. Positive content is graphed as 13-period moving averages centred around a given week. The railway share index is calculated from weekly share price tables in Railway Times. Capital gains are weighted by the previous period's market capitalization.
Panel B: Weekly Positive Content of Railway Times' Editorials using Subjective Assessment, Oct 1843-Oct 1847

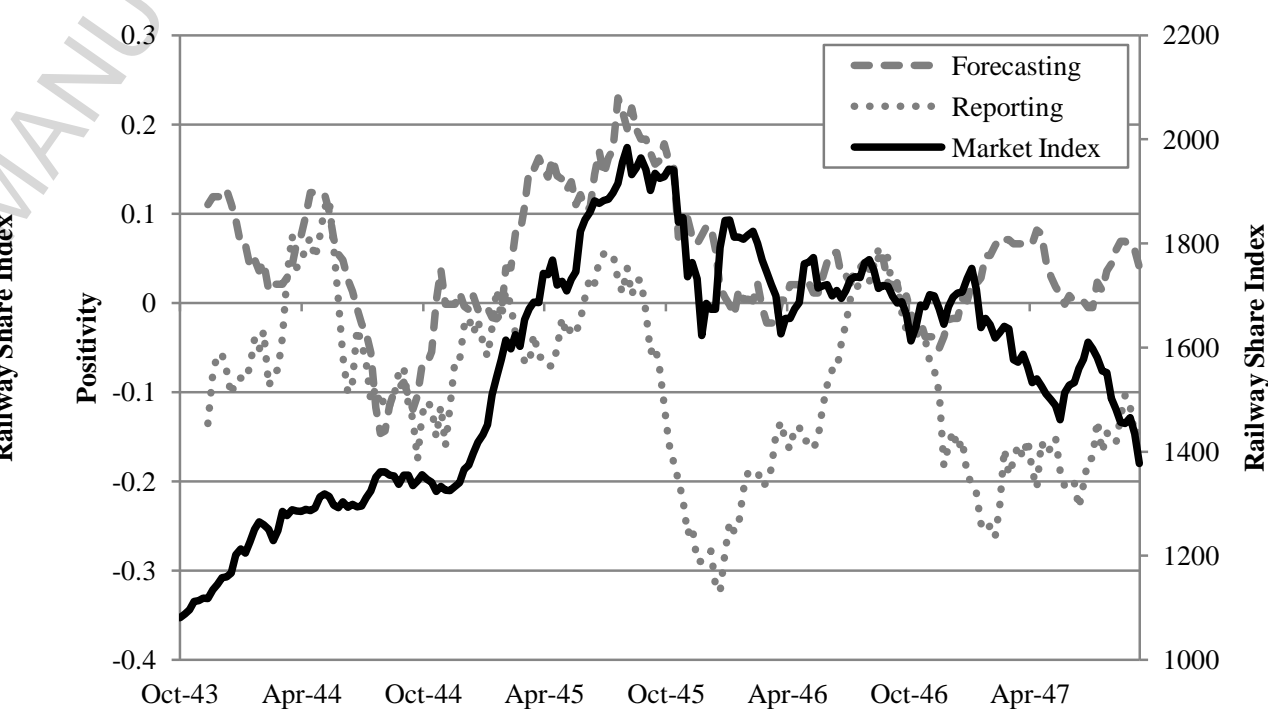

Notes: Forecasting is a subjective assessment of how positive or negative the forecasts made in the Railway Times' editorials were in a given week, with Reporting being a subjective assessment of how positive or negative the reporting of events were. Each column for each week was scored +1 for positive, 0 for neutral, or -1 for negative, for each measure and the average for each week was calculated. Forecasting and Reporting are both graphed as 13period moving averages centred around a given week. The railway share index is calculated from weekly share price tables in Railway Times. Capital gains are weighted by the previous period's market capitalization. 
Figure 2. Sentiment of Economist's Railway Supplement

\section{Panel A: Weekly Positive Content of \\ Economist's Railway Supplement using LIWC Software, 1845-50}

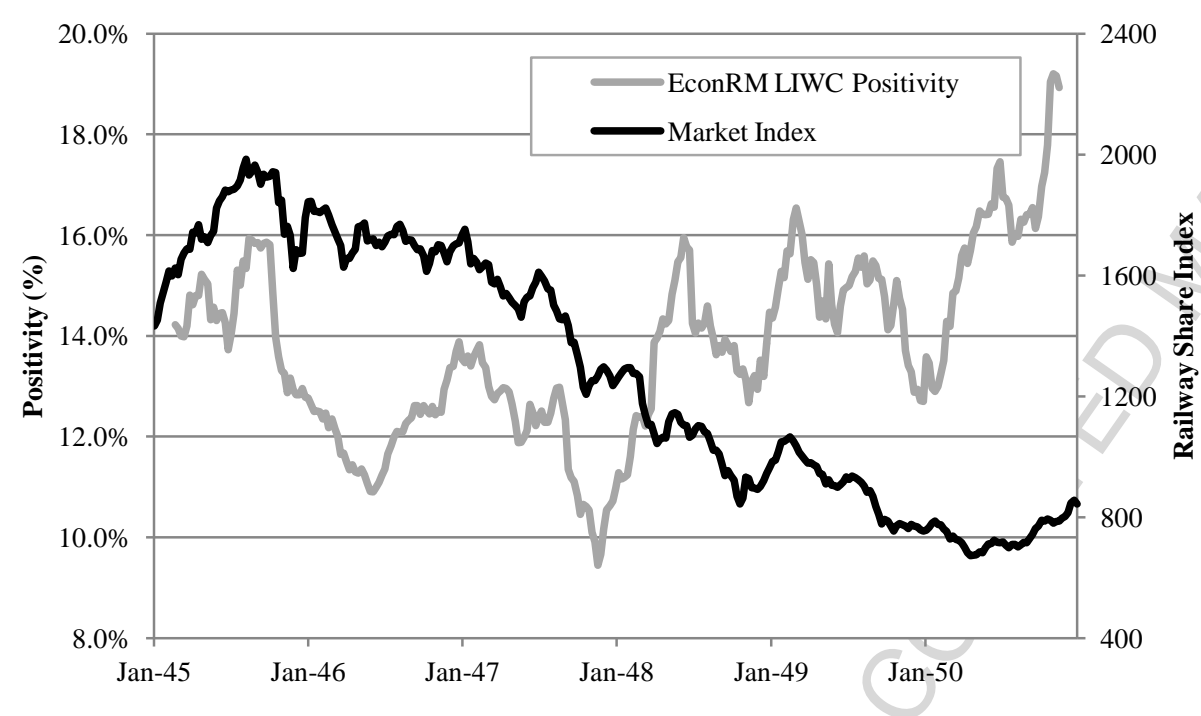

Notes: LIWC Positivity is the percentage of positive words, as defined by Linguistic Inquiry and Word Count (LIWC), in an article divided by the psychological processes word count,. Positive content is graphed as 13-period moving averages centred around a given week. The railway share index is calculated from weekly share price tables in Railway Times. Capital gains are weighted by the previous period's market capitalization. The Economist's Railway Supplement began publication in January 1845.
Panel B: Weekly Positive Content of Economist's Railway Supplement using Subjective Assessment, Jan 1845-Oct 1847

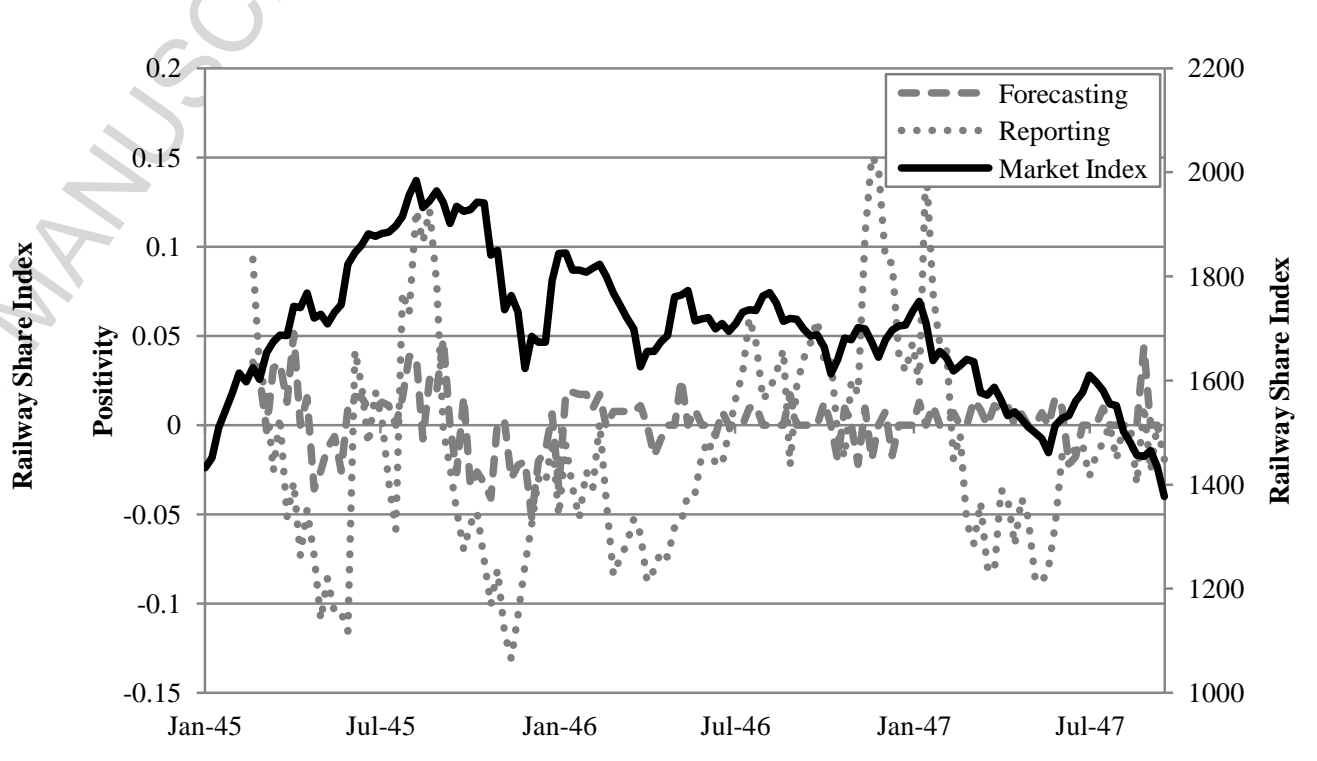

Notes: Forecasting is a subjective assessment of how positive or negative the forecasts made in the Economist's Railway Supplement were in a given week, with Reporting being a subjective assessment of how positive or negative the reporting of events were. Each column for each week was scored +1 for positive, 0 for neutral, or -1 for negative, for each measure and the average for each week was calculated. Forecasting and Reporting are both graphed as 13-period moving averages centred around a given week. The railway share index is calculated from weekly share price tables in Railway Times. Capital gains are weighted by the previous period's market capitalization. The Economist's Railway Supplement began publication in January 1845. 
Figure 3. Sentiment of Economist's Front Page

Panel A: Weekly Positive Content of Economist's Front Page using LIWC Software, Sept 1843-Dec 50

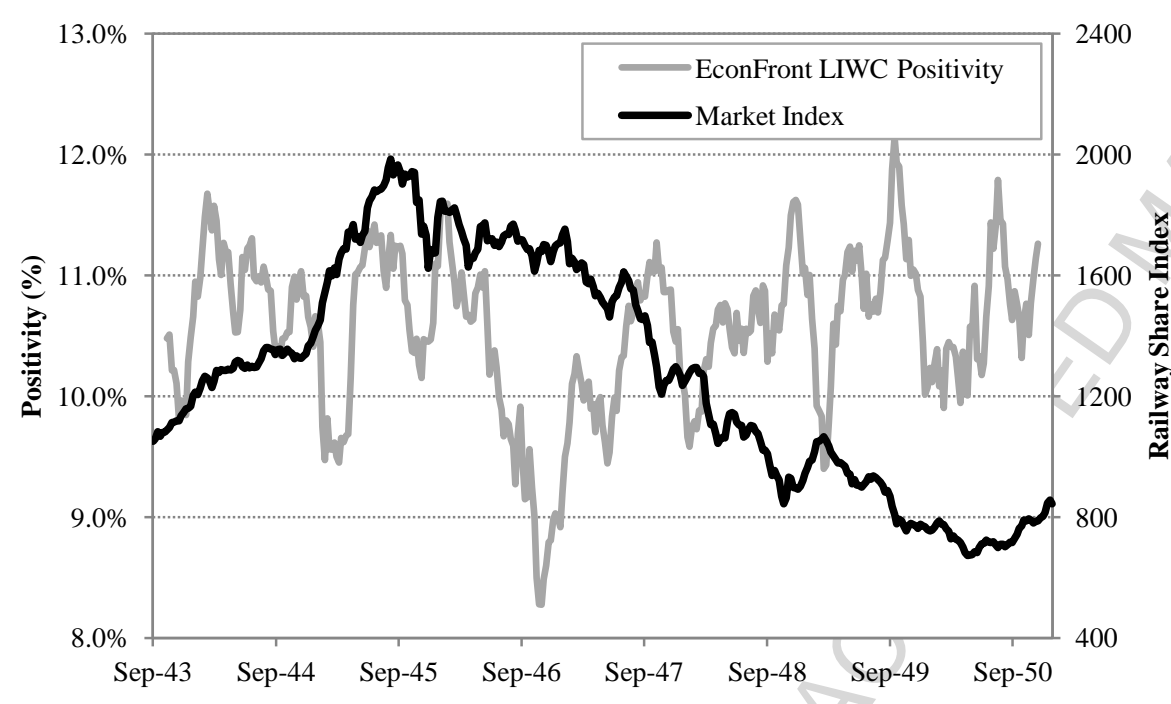

Notes: LIWC Positivity is the percentage of positive words, as defined by Linguistic Inquiry and Word Count (LIWC), in an article divided by the psychological processes word count.. Positive content is graphed as 13-period moving averages centred around a given week. The railway share index is calculated from weekly share price tables in Railway Times. Capital gains are weighted by the previous period's market capitalization. The Economist's front page began publication in September 1843.
Panel B: Weekly Positive Content of Economist's Front Page using Subjective Assessment, Oct 1843-Oct 47

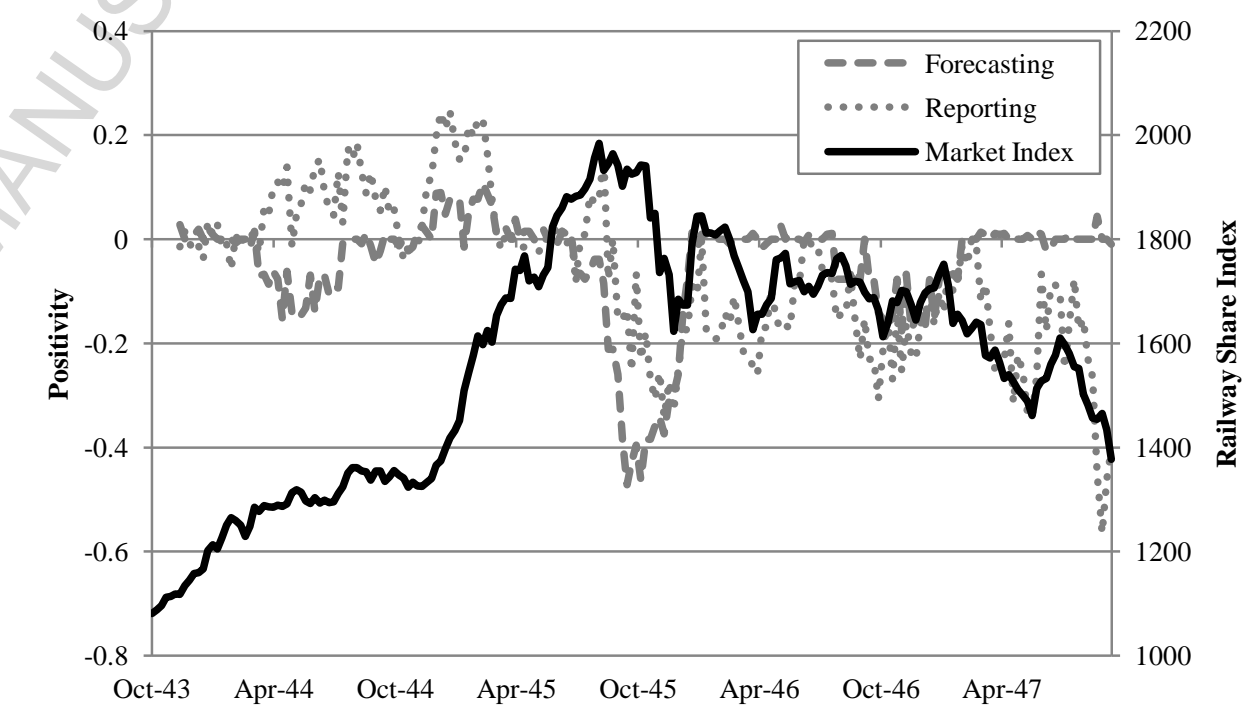

Notes: Forecasting is a subjective assessment of how positive or negative the forecasts made in the Economist's front page were in a given week, with Reporting being a subjective assessment of how positive or negative the reporting of events were. Each column for each week was scored +1 for positive, 0 for neutral, or -1 for negative, for each measure and the average for each week was calculated. Forecasting and Reporting are both graphed as 13period moving averages centred around a given week. The railway share index is calculated from weekly share price tables in Railway Times. Capital gains are weighted by the previous period's market capitalization. 
Figure 4. Index of Railway Excess Returns in the Weeks Before and After Publication of Editorials in The Times and The Economist

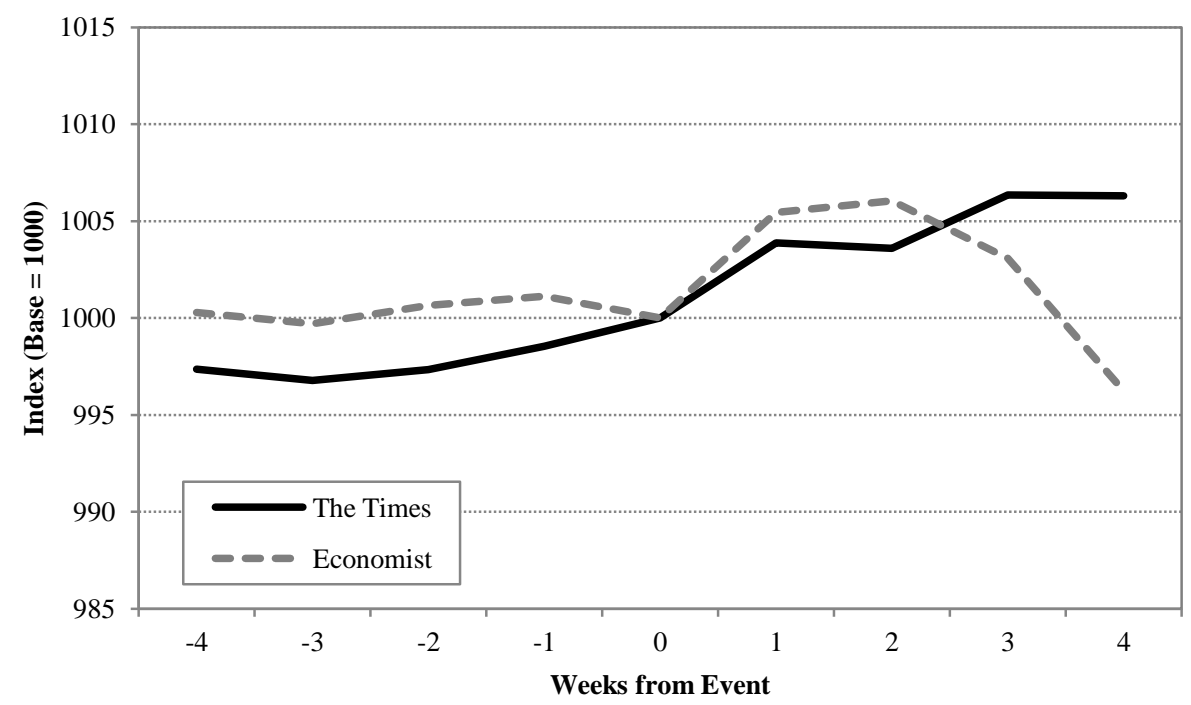

Notes: Excess returns calculated as railway returns minus non-railway returns, based on market indices of both which have been calculated by weighting individual stocks by their market capitalisation. Index begins at a level of 1,000 at the start of the week in which an editorial is published. 
Figure 5. Market Indices of Railway Shares by Extent of Media Coverage

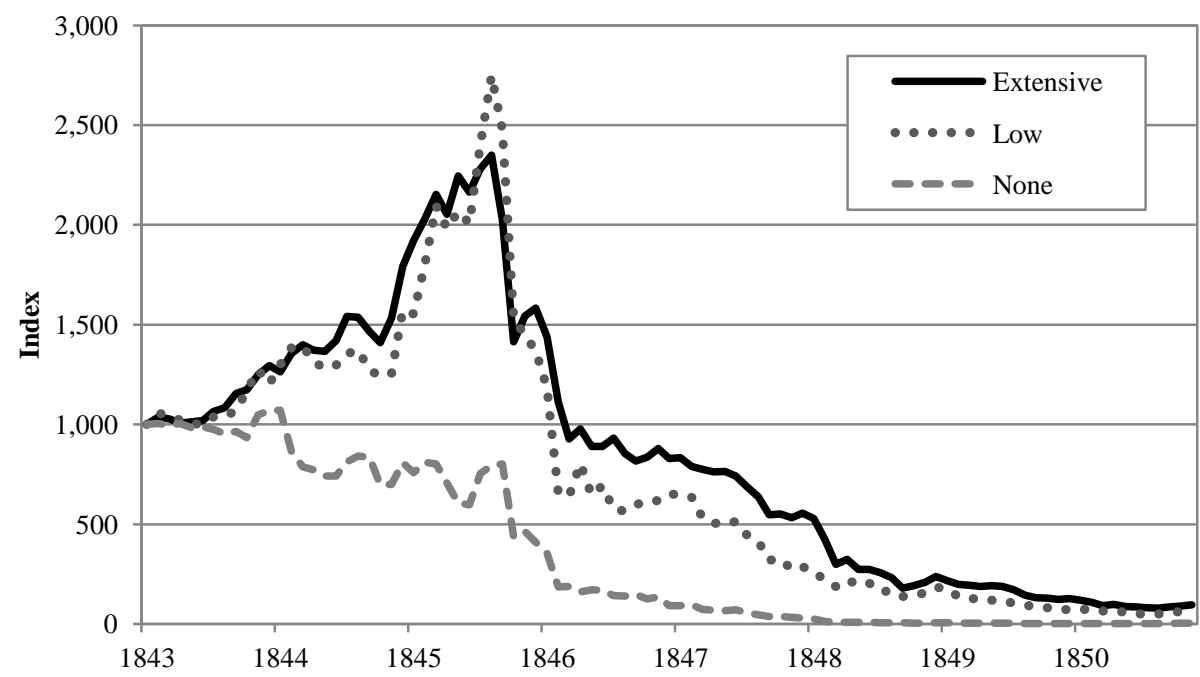

Notes: Stocks allocated to portfolios based on the extent of media coverage during the previous month. Monthly returns for each stock calculated as the change in the log of price, controlling for changes in capital. Monthly returns calculated for each portfolio based on an equally-weighted average of individual stock returns. Market indices calculated from these returns, using a base of 1,000 for January 1843. 
Figure 6. Market Index of Established Railway Shares and Dividend / Par Ratio for those Railways

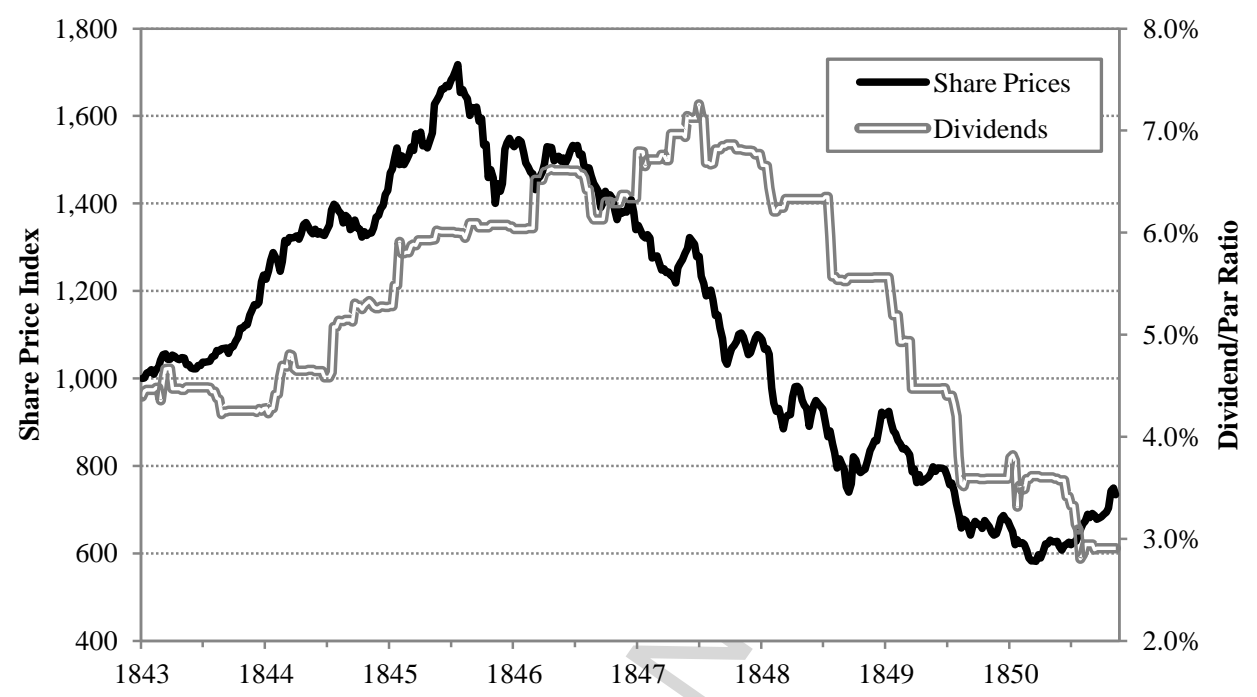

Notes: Sample includes those established railways which were operating from the beginning of the Mania, before January 1843, and therefore potentially capable of paying dividends. The railway share index is calculated from weekly share price tables in Railway Times. Capital gains are weighted by the previous period's market capitalization. The dividend / par ratio is the amount of dividends paid by all railways divided by the total par (paid-up capital) of the railway industry. Dividends were obtained from the Course of the Exchange. 
Figure 7. Adverts for New Railway Promotions in the Railway Times and Number of Railway Securities Listed on London Stock Exchange, 1843-50

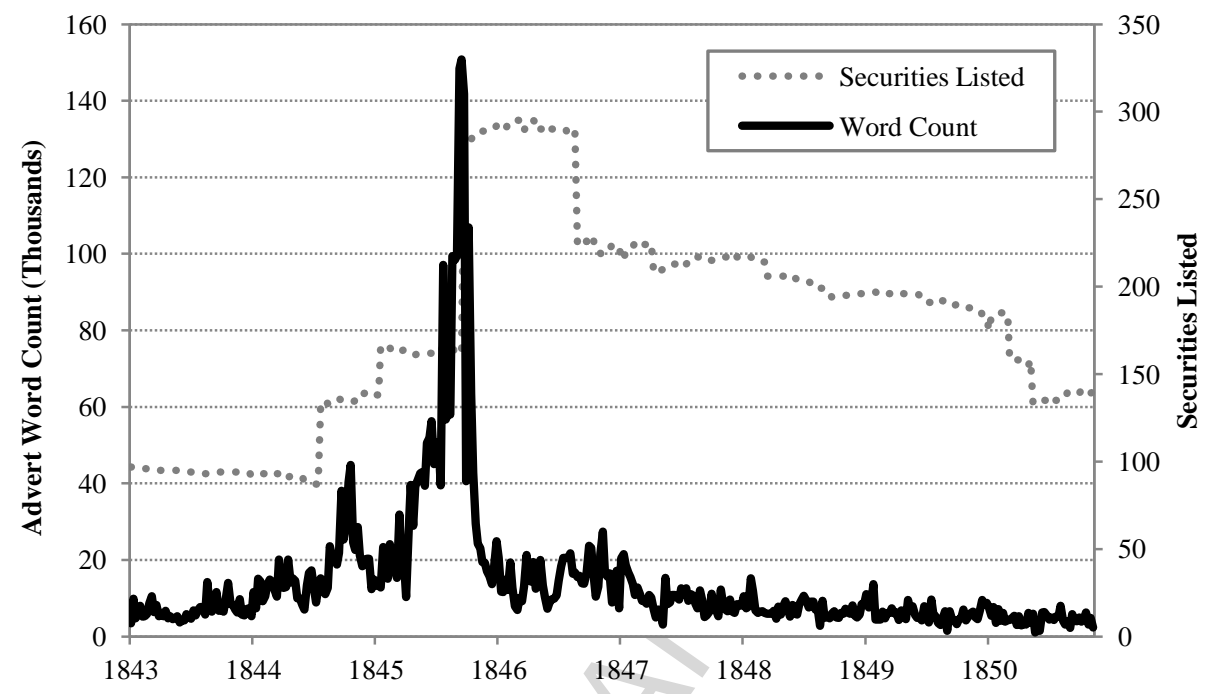

Notes: Word count of adverts was obtained by scanning in all company adverts in the Railway Times and running the scans through the Linguistic Inquiry and Word Count (LIWC) software. The number of securities listed was calculated from weekly share price tables in Railway Times. 